\title{
A Critical Review on the Plants Used for the Treatment of Ulcer in Kerala
}

\section{Jincy J*, Nancy J, Jipnomon J and Vinod B}

Department of Pharmacology, St. Joseph's College of Pharmacy, India

${ }^{*}$ Corresponding author: Jincy Jacob, Department of Pharmacology, St. Joseph's College of Pharmacy, Cherthala, Kerala, India-688 524, Tel: +91 8078467305; Email: jincyjacobtj.7@gmail.com

\section{Review Article \\ Volume 3 Issue 2}

Received Date: April 02, 2019

Published Date: May 15, 2019

DOI: $10.23880 /$ oajpr-16000175

\section{Abstract}

Peptic ulcer disease and its complications remain the cause of significant morbidity worldwide, representing a major burden for health care resources. Although potent anti-ulcer drugs are available, most of them produce several toxicities, thus emphasizing the need to search for new alternatives. As high as $80 \%$ of the world population depends on plantderived medicines for the first line of primary health care, reinforcing the theory that plant extracts can be good sources of new drugs. This review focuses to consolidate the evidence-based information on antiulcer plants used in Kerala accumulated in databases (Google Scholar, PubMed, Scopus, Science Direct and Web of Science) upto January 2019. Plants like Acacia nilotica L., Achyranthes aspera Linn., Aegle marmelose L., Alillum sativum L., Aloe barbadensis Miller, Annona muricata L., Bacopa monnieri Linn., Carica papaya Linn., Centella asiatica Linn., Curcuma longa Linn., Elatoria cardamom L., Hibiscus rosa-sinensis L., Mangifera indica L., Mimosa pudica L., Moringa oleifera L., Ocimum sanctum Linn., Piper nigrum L., Phyllanthus embilica L., Terminalia chebula Retz., and Zingibera officinalis Roscoe. are available in Kerala, reported with antiulcer property. The secondary metabolites present in the plants like alkaloids, flavanoids, terpenoids, tannins, glycosides, terpines, and resins also have an important role in reliving ulcers due to its antisecretory, antioxidant, and cytoprotective properties. This review summarizes the botany, ethnopharmacology, phytochemistry and mechanism of action of antiulcer plants.

Keywords: Antiulcer; Alkaloids; Flavonoids; Terpenoids

Abbreviations: HCL: Hydrochloric Acid; NSAIDs: Nonsteroidal Anti-Inflammatory Drugs; PGs: Prostaglandins; AChE: Acetyl Cholinesterase; CMC: Carboxymethyl Cellulose; SST2: Somatostatin receptor 2; AST: Aspartate aminotransferase, ALT: Alanine aminotransferase, PCV: Packed cell volume, LPO: Lipid peroxidation, MCHC: Mean cell hemoglobin concentration.

\section{Introduction}

Peptic ulcer is a group of ulcerative disorders that occur in the areas of the upper gastrointestinal tract that 


\section{Open Access Journal of Pharmaceutical Research}

are exposed to acid-pepsin secretions. The most common causes of peptic ulcer are $H$. pylori infection and NSAID use. It can affect one or all layers of the stomach or duodenum. The two most common types of peptic ulcer are gastric ulcer and duodenal ulcer [1]. Duodenal ulcer is 2-4 times more prevalent than gastric ulcer type [2]. Gastric ulcers occur in the stomach, characterized by pain and are common in older age group. Nausea, vomiting and weight loss are the other symptoms of gastric ulcers. Although patients with gastric ulcers have normal or diminished acid production, yet ulcers may occur even in complete absence of acid [3]. Duodenal ulcers are found at the beginning of small intestine and are characterized by severe pain with burning sensation in upper abdomen that awakens patients from sleep. Generally, pain occurs when the stomach is empty and relieves after eating. Duodenal ulcer is more common in younger individuals and predominantly affects males [4].

\section{Prevalence of Peptic Ulcer}

Peptic ulcer is one of the world's major gastrointestinal disorders and affecting $10 \%$ of the world population [5]. About 19 out of 20 peptic ulcers are duodenal. It is estimated that 15000 deaths occur each year as a consequence of peptic ulcer. The annual incidence estimates of peptic ulcer hemorrhage and perforation were $19.4-57$ and $3.8-14$ per 100,000 individuals, respectively. The average 7 -day recurrence of hemorrhage was $13.9 \%$ and the average long-term recurrence of perforation was $12.2 \%$ [6]. According to the latest WHO data published in 2017 peptic ulcer disease deaths in India reached 57,658 or $0.66 \%$ of total deaths. The age adjusted death rate is 5.79 per 100,000 of population ranks India 53 in the world [7]. In the Indian pharmaceutical industry, antacids and antiulcer drugs share 6.2 billion rupees and occupy $4.3 \%$ of the market share [8].

Peptic ulcer occurs in the gastrointestinal tract which is exposed to gastric acid and pepsin i.e. the stomach and duodenum. The etiology of peptic ulcer is not clearly known. It results probably due to the imbalance between aggressive and protective factors in the stomach [9]. Aggressive factors include Helicobacter pylori, hydrochloric acid $(\mathrm{HCl})$, pepsins, nonsteroidal antiinflammatory drugs (NSAIDs), bile acids, ischemia, hypoxia, smoking and alcohol, while defensive factors include bicarbonate, mucus layer, mucosal blood flows, prostaglandins (PGs) and growth factors [10].

In this context, the use of medicinal plants has gained interest of many researchers. Natural products are in continuous expansion all over the world and became the most attractive source of new drug and relatively less expensive, safe to use even at higher doses for the treatment and prevention of many diseases [11]. According to World Health Organization, medicinal plants would be the best source to obtain a variety of drugs. Therefore, such plants should be investigated to better understand their properties, safety and efficacy [12]. In order to achieve this aim, various sources like ancient traditional books, journals, libraries and internet were explored for each of the medicinal plants for peptic ulcers and all retrieved articles were evaluated to achieve clinical evidence for their efficacy and possible mechanisms. There by this review aims to summarize the antiulcer activity of medicinal plants found in Kerala (Table 1).

\section{Acacia nilotica (L.)}

A. nilotca belongs to the family of Mimosaceae. It is commonly known as "babul tree" and locally called as karuvelam. A. nilotica is commonly found all over India in dry and sandy localities, this species occurs only in Travancore district in low altitude dry forests where it attains larger dimensions [13]. The bark, leaves pods and flowers have traditionally been proved for various ailments like cancer, cold, congestion, cough, diarrhea, dysentery, fever, hypertension, hemorrhoid, ophthalmic, sclerosis, small pox, tuberculosis, leprosy, bleeding piles, leucoderma and menstrual problems [14]. Pharmacologically reported activities include antiinflammatory [15], antioxidant [16], antidiarrhoeal [17], antihypertensive and antispasmodic [18], antibacterial [19], anthelmintic [20], antifungal [21], antiplatelet aggregatory [22], analgesic [15], antipyretic [23], antiviral [24], anticancer [25] antidiabetic [26] and acetyl cholinesterase (AChE) inhibitory [27]. Phytochemically tannins 25\%-60\%, mucilage 20\%-30\%, flavonoids, resins, saponins \& alkaloids have been isolated from different parts of $A$. nilotica [28]. The gastroprotective effect of $A$. nilotica young seedless pod extract was evaluated for antiulcer activity. Different extracts like ethanolic, 50\% hydroethanolic (50:50), 70\% hydroethanolic (70:30) and aqueous of young seedless pods were examined in pylorus ligation, swimming stress and NSAID induced gastric ulcers in wistar rats.

The hydroethanolic extracts $70 \%$ and $50 \%$ at the dose of 100 and $200 \mathrm{mg} / \mathrm{kg}$ significantly $(\mathrm{P} \leq 0.05)$ reduced gastric volume, free acidity, total acidity, ulcer index and increased the mucin content. Further the $70 \%$ hydroethanolic extract also showed better protection as compared to $50 \%$ hydroethanolic extract, which was 


\section{Open Access Journal of Pharmaceutical Research}

comparable to cimetidine treatment. Whereas, ethanolic and aqueous extracts were not found to be effective in reducing pylorus ligation-induced gastric ulceration. In swimming stress and NSAID induced ulcer models the 70\% hydroethanolic extract at 100 and $200 \mathrm{mg} / \mathrm{kg}$ significantly $(\mathrm{P} \leq 0.05)$ decreased the ulcer index and increased the mucin content. Similar protection was also observed after treatment with diazepam [28]. From the study they concluded that the hydroethanolic extract of young seedless pods of $A$. nilotica has antiulcer activity in pylorus ligation, swimming stress and indomethacin induced ulcer rat models. Moreover the $70 \%$ hydroethanolic extract contains more amounts of phenolic components and it shown high antiulcer activity, which indicates that the phenolic component of the extract was found to be responsible for the activity of the extracts [28].

\section{Achyranthes aspera L.}

A.aspera (Amaranthaceae) is commonly known as kadaladi, vankadaladi, valiyakadaladi. The plant is found in Kottayam, Kasargod, Trivandrum, Malapuram and Alapuzha district in dry deciduous forests and forest plantations, also in the plains [13]. Traditionally the plant has been used to treat fever especially for malarial fever, dysentery, asthma, hypertension, and diabetes [29]. Pharmacologically reported activities include diuretic, anti-inflammatory, antifungal, abortifaciant, larvicidel, hypoglycemic, antifertility and anticancer [30]. The major phytochemical constituents like carbohydrates, sugars, alkaloids, saponins, flavonoids, tannins are present in $A$. aspera [29]. The gastroprotective effect of $A$. aspera leaves were evaluated on pyloric ligation and ethanol induced ulcer model by Vijay, et al. [29]. A. aspera leaves 200, 400 and $600 \mathrm{mg} / \mathrm{kg}$ ethanolic extract significantly reduced the ulcer index $\mathrm{P} \leq 0.05$ by $200 \mathrm{mg} / \mathrm{kg}, \mathrm{P} \leq 0.01$ by $400 \mathrm{mg} / \mathrm{kg}$, and $\mathrm{P} \leq 0.001$ by $600 \mathrm{mg} / \mathrm{kg}$ when compared to the ulcer control. In addition to this it also reduced the total acidity, free acidity, $\mathrm{pH}$ and gastric volume. The extent of gastro protection showed by the A. aspera extract $600 \mathrm{mg} / \mathrm{kg}$ was $59.55 \%$ and $35.58 \%$ respectively against pyloric ligation and ethanol induced ulceration when compared to the standard drug omeprazole $83.14 \%$ and $50.25 \%$ respectively. A. aspera exerts cytoprotective effect in addition to its gastric antisecretory activity that could be due to the presence of flavonoids and tannins responsible for its protective effect by maintaining an efficient gastric mucosal microvascular supply [29].

\section{Aegle marmelose $L$.}

A.marmelose (Rutaceae), commonly known as koolakam, koovalam, vilvam, mavilavu. The plant chiefly grows throughout Kerala in dry, open forests on hills and plains at altitudes from sea level to around 1200m [13]. Traditionally, the unripe fruits are used as astringent, aid in digestion and stomach irritation. The half-ripe fruits are astringent, digestive and antidiarrheal. The ripe fruits are supposed to be more useful than the raw fruits and are used to prevent subacute and chronic dysentery [31]. Their leaves are traditionally used for the treatment of fever, abdominal pain, urinary troubles, heart palpitation, dysentery, dyspepsia, stomach pain, seminal weakness, vomiting and swellings [32]. Antioxidant [33], hepatoprotective [34], antidiabetic [35], cardio protective [36], antipyretic, anti-inflammatory, and analgesic [37], antimicrobial [38], antifungal [39], antidyslipidemic [40], anticancer [41], and antiulcer [42], are the pharmacologically reported activities. The antiulcer activity of 200 and $400 \mathrm{mg} / \mathrm{kg}$ ethanolic extract of $A$. marmelose leaves on rats were evaluated by Sharmin, et al. [42].

The ethanolic extract of $A$. marmelose leaves at 400 $\mathrm{mg} / \mathrm{kg}$ body weight showed significant reduction in ulcer spots in the stomach when compared to the control. Moreover, administration of ethanolic extract of $A$. marmelose and standard drug omeprazole both produced highly significant $(\mathrm{P} \leq 0.001)$ antiulcer effect compared to control group. Percentage protection of ulcer with 400 $\mathrm{mg} / \mathrm{kg}$ body weight of ethanolic extract of $A$. marmelose was found to be $56.33 \%$ when compared to the standard antiulcer drug omeprazole (50.44\%) [42].

\section{Alillum sativum L.}

A. sativum (Liliaceae) is commonly known as garlic and locally known as veluthulli. This plant is a bulbous herb found in Idukki and Palakkad districts of Kerala [13]. Traditionally, it has been used in reducing cholesterol, blood pressure, free radicle scavenger, anti-platelet activity, thromboxane inhibiting activity and cardioprotective [43]. Pharmacologically reported activities are antimicrobial, antioxidant [44], antihypertensive [45], cardioprotective [46], antiatherosclerotic [47], antidiabetic [48], cancer chemopreventive [49], neuroprotective [50], nephroprotective [51] and immunomodulatory [52]. Potentially active phytochemical constituents in this plant are alliin, allicin, allinase, ajoene, peroxidase, arginine, selenium, germanium and tellurium [43]. The antiulcer activity of aqueous extract of $A$. sativum in pyloric ligation induced peptic ulcer in rats was evaluated by Arunachala, et al. [53]. The rats were treated with 200, 300, and 400 $\mathrm{mg} / \mathrm{kg}$ of aqueous extract of $A$. sativum for 10 days and it reduced the gastric volume, total acidity and free acidity, 


\section{Open Access Journal of Pharmaceutical Research}

ulcerative index, total calcium, thiobarbituric acid reactive substances, myeloperoxidase levels and increase in total protein and reduced glutathione level in a dose dependent manner. The $400 \mathrm{mg} / \mathrm{kg}$ of aqueous extract of $A$. sativum showed significant $(\mathrm{P} \leq 0.05)$ ulcer protective effect when compared to the standard ranitidine treated group. It has been concluded that the ulcer protective effect of aqueous extract of $A$. sativum may be due to its antioxidant, antiinflammatory, immunosuppressive and anti-secretary action. Therefore, the aqueous extract of $A$. sativum may be a potent herbal candidate for the treatment of peptic ulcers [53].

\section{Aloe barbadensis Miller}

A. barbadensis is a perennial drought resisting herb belongs to the family Liliaceae. It is commonly known as aloe vera and locally known as kattarvazha, kattalai, kattuvala and ghritakumari. This plant is found throughout Kerala [13]. Traditionally the plant is used to treat burns, allergic reactions, acid indigesions, ulcers, diabetes skin diseases, uterine tonic, blood purifier, dysentery, diarrhea, piles and inflammatory conditions. Pharmacologically reported activities are anti-aging [54], antioxidant and immunomodulatory [55], antibacterial, antifungal [56], antiviral [57], anti-mutagenic [58], antidiabetic [59], and anti -ulcer [60]. The antiulcer effect of aloe vera was evaluated in non-steroidal antiinflammatory drug induced peptic ulcers in albino rats by Sai, et al. [60]. A. barbadensis $200 \mathrm{mg} / \mathrm{kg}$ showed antiulcer effect with mean ulcer index of $20 \pm 1.79$ compared to the standard omeprazole treated group with mean ulcer index of $10 \pm 1.96$. A. barbadensis possessed cytoprotective effects and acid reducing effects like omeprazole [60].

\section{Annona muricata $\mathrm{L}$.}

A. muricata (Annonaceae) is commonly known as guanabana, graviola, prickly custard apple and locally known as cancer chakka, mullanjakka, mulluathi, mullathi. A. muricata trees are found throughout Kerala [13]. Traditionally, A. muricata has been used for fever, pain, respiratory and skin illness, internal and external parasites, bacterial infections, hypertension, inflammation, diabetes and cancer [61]. The pharmacologically reported activities are antimicrobial [62], anti-inflammatory [63], anti-protozoan [64], antioxidant [65], anxiolytic and antistress [66], antitumoral [67], antiulcer [68], wound healing [69], hepato-protective [70], hypoglycemic [71], and hypotensive activities [72]. The antiulcerogenic activity of the hydroalcoholic extract of leaves of $A$. muricata was evaluated in mice by Elizangela, et al. [73]. The mice were treated with 50, 100, 200 and $400 \mathrm{mg} / \mathrm{kg}$ of hydroalcoholic extract of $A$. muricata. Gastric lesions were induced in mice by absolute ethanol, acidified ethanol and indomethacin. In ethanol induced ulcer model hydroalcoholic extract of $A$. muricata pretreatment at doses of $50,100,200$ and $400 \mathrm{mg} / \mathrm{kg}$ before the administration of absolute ethanol produced a significant reduction in lesion area by $92.89 \%, 94.13 \%, 97.79 \%$ and $96.55 \%$, respectively. From this detail it has been found that the hydroalcoholic extract of $A$. murcata at a dose of 200 and $400 \mathrm{mg} / \mathrm{kg}$ was more effective than the standard drug omeprazole (30 mg/kg p.o.), which showed a significant reduction in gastric lesion areas of $95.79 \%$. Whereas in indomethacin induced ulcer model hydroalcoholic extract of $A$. muricata at $200 \mathrm{mg} / \mathrm{kg}$ proved to be the most effective dose, by reducing the incidence of ulcers by $94.13 \%$. Hydroalcoholic extract of $A$. muricata at $400 \mathrm{mg} / \mathrm{kg}$ also decreased the incidence of ulcers significantly by $91.67 \%$. Omeprazole $(30 \mathrm{mg} / \mathrm{kg}$ ) reduced lesion rates by $96.82 \%$ compared with the ulcer control group. In acute gastric lesions induced study, the mice by acidified ethanol pretreatment with hydroalcoholic extract of $A$. muricata at doses of 50, 100, 200 and $400 \mathrm{mg} / \mathrm{kg}$, showed a reduction in lesions of $47.69 \%, 76.23 \%, 80.20 \%$ and $93.22 \%$, respectively. At a dose of $400 \mathrm{mg} / \mathrm{kg}$, hydroalcoholic extract $A$. muricata was as effective as the standard drug (omeprazole), which reduced the ulcer area by $93.22 \%$. The study confirmed that the gastroprotective action of $A$. muricata leaves and it's activity is modulated or mediated by the synthesis of prostaglandins, thereby determining the phytotherapeutic potential of this species to treat stomach ulcers and gastritis [73].

\section{Bacopa monnieri L.}

B. monnieri (Scrophulariaceae) is commonly known as bacopa, thyme leaved gratiola and locally known as brahmi, neerbrahmi. This plant is found throughout Kerala [13]. Traditionally it has been used to improve memory and intellect, anxiety, poor cognition and lack of concentration, as a diuretic and as an energizer for the nervous system and the heart. Specific uses include treatment of asthma, insanity and epilepsy. The plant has been utilized extensively as a nootropic, digestive aid and to improve learning and respiratory function [74]. Pharmacologically reported activities are sedative and tranquillizer [75], cogntion [76], antioxidant [77], antidepressant [78], antianxiety [79], adaptogenic [80] and gastrointestinal disorders [81]. The antiulcerogenic activity of B. Monnieri on ethanol-induced gastric ulcer model was evaluated by comparing the efficacy of 200 and $400 \mathrm{mg} / \mathrm{kg}$ of aqueous, ethanolic and carbon tetrachloride extracts [82]. The histopathological results 


\section{Open Access Journal of Pharmaceutical Research}

and microscopic damage scores of the treated animals with aqueous and carbon tetrachloride extracts of $B$. monnieri exhibited moderate to poor protection against gastric ulcers when compared with treatment with standard drug (Omeprazole). On the other hand, the ethanolic extract of B. monnieri (200 and $400 \mathrm{mg} / \mathrm{kg} \mathrm{b.w.)}$ potentially regulated the inflammatory response that correspond to omeprazole $(20 \mathrm{mg} / \mathrm{kg}$ b.w.) as evidenced by reduced ulcer index and microscopic score along with the results of histopathological evaluation. It has been reported that flavonoids and phenols are present in the three extracts. The presence of high flavonoid and phenolic contents may favor the ethanolic extract of $B$. monnieri to possess significant protective effect against ulcer when compared with other two extracts. Pretreatment with both doses (200 and $400 \mathrm{mg} / \mathrm{kg}$ ) of all three extracts (except carbon tetrachloride extract of $B$. monnieri of $200 \mathrm{mg} / \mathrm{kg})$ showed significant result $(\mathrm{P} \leq 0.01)$ for UI value when compared with ulcer control. Both aqueous and carbon tetrachloride extracts of $B$. monnieri showed significant difference $(\mathrm{P} \leq 0.01)$ in UI values when compared with the reference drug (omeprazole, 20 $\mathrm{mg} / \mathrm{kg})$. The ethanolic extract of B. monnieri $(400 \mathrm{mg} / \mathrm{kg})$ showed significant protection against gastric ulcer same as omeprazole (20 mg/kg b.w.) [82].

\section{Carica papaya L.}

C. papaya belongs to the family Caricaceae. It is locally known as papaya, kappalanga, karmmoose, kappanga, ampapaya. This herbacious tree is found throughout Kerala [13]. Traditionally it has been used as antihypertensive, wound healing, anti-inflammatory, anthelmintic and antiulcer [83]. Pharmacologically reported activities are antioxidant [84], antihypertensive [85], anti-inflammatory [86], antimicrobial [87], antifungal [88], histaminergic [89], diuretic [90], antiamoebic [91], anti-tumour and immunomodulatory [92], anthelminthic [93], antimalarial [94], hypoglycemic [95], antiulcer [96] and anti-sickling [97]. Papain, chymopapain, pectin, carpain, carposide, carotinoids, vitamin $\mathrm{C}$ and antheraxanthin are pharmacologically important compound in this plant [83]. Ramandeep, et al. evaluated the antiulcer activity of hydroalcoholic extract of unripe fruit of C. papaya in experimental rats. In this study they were used 250 and $500 \mathrm{mg} / \mathrm{kg}$ of hydroalcoholic extract of C. papaya in pylorus ligation and forced swimming induced ulcer models [98]. In both ulcer models, reduced ulcer index, gastric volume, free acidity and total acidity suggested that hydroalcoholic extract of $C$. papaya fruits have the antisecretory and antiulcerogenic activity. From the study it has been found that the hydroalcoholic extract of C. papaya $250 \mathrm{mg} / \mathrm{kg}$ showed decreased number of erosions in mucosa but still there is inflammation with areas of haemorrhage. Further, there was a decreased extent of gastric mucosal rupture. Whereas, $500 \mathrm{mg} / \mathrm{kg}$ effectively decreased the epithelial cell loss, gastric lesions and haemorrhage [98].

\section{Centella asiatica $\mathrm{L}$.}

C. asiatica (Apiaceae) is commonly known as gotu kola, Indian penny -wort, pohekula, sadeleaf and locally known as kodangal, kudakan, mutthil, vellara. C. asiatica is a prostate herb found throughout Kerala in wet places of the plain and deciduous forest [13]. Traditionally it has been used as a best herb for improving memory and intellect. It also used in CNS disorders like epilepsy, schizophrenia and cognitive dysfunction, renal stones, leprosy and skin diseases, anorexia and asthma. In other traditional systems, it has been additionally used in the management of diarrhoea, cholera, measles, jaundice, leucorrhoea, hematemesis, hepatitis, urethritis, toothache, syphilis, smallpox, neuralgia, rheumatism and as an antipyretic, analgesic and anti-inflammatory. Poultices have been used to treat contusions, closed fractures, sprains and furunculosis [99]. Pharmacologically reported activities include management of fibroblast proliferation and collagen synthesis [100], antioxidant activity [101], antiulcer [102], anticancer [103], anti-bacterial activity [104] and anti-inflammatory activity [105]. The roots are rich in amino acids, especially aspartic, glutamic, serine, threonine, alanine, lysine and histidine [99].

The antiulcer activity of $C$. asiatica leaves extract against ethanol induced gastric mucosal injury in rats was evaluated by Abdulla, et al. [106]. Adult Sprague Dawley rats treated orally with carboxymethyl cellulose (CMC) solution (ulcer control group), Omeprazole $20 \mathrm{mg} / \mathrm{kg}$ (reference group), and 100, 200 and $400 \mathrm{mg} / \mathrm{kg}$ C. asiatica leaf extract in CMC solution (experimental groups) for the experiment. C. asiatica leaf extract showed a dose dependent reduction in the gastric ulcer, edema and leucocytes infiltration of mucosal layers when compared to the control. The protection was most prominent at a dose $400 \mathrm{mg} / \mathrm{kg}$ of leaves extract. From the study it has been found that the mechanism of antiulcer activity may be due to antioxidant, anti-inflammatory and also due to the reduction in the gastric motility [106].

\section{Curcuma longa L.}

C. longa Linn. (Zingiberaceae) is commonly known as turmeric and locally known as manjal. This plant is a rhizomatous herb found throughout Kerala [13]. Traditionally it has been used for dressing wounds, treat bites, burns, acne, skin diseases, respiratory ailments, 


\section{Open Access Journal of Pharmaceutical Research}

dental diseases, digestive disorders such as dyspepsia and acidity, indigestion, flatulence, ulcers, antioxidant, antifertility as well to alleviate the hallucinatory effects of hashish, and other psychotropic drugs [107]. Pharmacologically reported activities are antiinflammatory [108], antioxidant [109], chemopreventive and chemotherapeutic activity [110], antiulcer [107], anticoagulant [111], antidiabetic [112], antimicrobial [113] antifungal [114] and antiviral [115]. Phytochemical constituents in this plant are curcumin, demethoxycurcumin, bisdemethoxycurcumin, protein, fat, minerals, carbohydrates, phellandrene, sabinene, cineol, borneol, zingiberene, and sesquiterpenes [111]. Karolin conducted a comparative evaluation of the antiulcer activity of curcumin and omeprazole during acute phase of gastric ulcer. Results obtained showed that curcumin and omeprazole significantly decreased gastric lesion formation $(\mathrm{P}<0.001)$ in the gastric wall from $33.15 \pm$ 3.899 lesions/animal in control group to $4.000 \pm 0.6602$ and to $8.215 \pm 0.8787$ lesions/ animal in treated groups with curcumin and omeprazole, respectively. Therefore, the preventive index was re-corded $85.75 \pm 2.851$ and $71.71 \pm 2.697 \%$ for curcumin and omeprazole treated group, respectively. It also reduced the plasma peroxide, gastric acidity and IL-6 whereas; gastric mucin content and VGEF level are increased. Curcumin exerts its antiulcer activity not only by affecting oxidative stress and total antioxidant capacity but also by inhibiting IL-6 secretion and preventing apoptosis. Furthermore, curcumin promotes gastric ulcer pre-venation/healing by induction of angiogenesis in the granular tissue of ulcers [116].

\section{Elatoria cardamom $\mathbf{L}$.}

E. cardamom belongs to the family of Zingiberaceae. It is commonly known as cardamom and locally known as ealakkaya, eallam, elam, elattari. This plant is found in Palakkad, Idukki, Kollam, Pathanamthitta, Malappuram, Kannur, Thiruvananthapuram, Thrissur and Wayanad districts of Kerala [13]. Traditionally it has been used for aromatic, cardiac, carminative, deodorant, digestive, diuretic, expectorant, purgative, stimulant, thirst reliever and tonic. It is also useful in asthma, burning sensation, cold and cough, diseases of bladder and kidney, flatulence, heart weakness, indigestion, scanty urine and piles [117]. Pharmacologically reported activities are antiinflammatory, analgesic, insecticidal, anthelmintic, laxative, antiulcer, diuretic. Terpineol, terpinene, cineol, limonene, sabinene are the phytochemical constituents in this plant [117]. The gastroprotective effect of cardamom was evaluated in the gastric lesions induced by asprin, ethanol and pylorous by Jamal, et al. [118]. Rats were treated with methanolic extract of cardamom, petroleum ether soluble fractions, petroleum ether insoluble fractions, essential oil and CMC [118].

First, they conducted experiment on ethanol induced ulcer model, in that experiment Wistar rats were treated with methanolic extract $(500,300$ and $100 \mathrm{mg} / \mathrm{kg})$, Petroleum ether soluble fraction $(50 \mathrm{mg} / \mathrm{kg})$, petroleum ether insoluble fraction $(450 \mathrm{mg} / \mathrm{kg})$ and essential oil $(50 \mathrm{mg} / \mathrm{kg})$ in order to determine the fraction containing most active principle. The pretreatment with methanolic extract $(500,300$ and $100 \mathrm{mg} / \mathrm{kg}$ ) showed a dose dependent reduction in the severity of the lesions. The petroleum ether soluble and petroleum ether insoluble fractions showed significant inhibition of ulceration by $50 \%$ and $54.8 \%$, respectively. Petroleum ether soluble fraction is found to be more active when compared to petroleum ether insoluble fractions and moreover petroleum ether soluble faction at a dose $100 \mathrm{mg} / \mathrm{kg}$ produced sub maximal response. The essential oil was found to be more active than petroleum ether soluble fractions $(73.3 \%$ and $50.0 \%$ inhibition, respectively). They found that the active principles in essential oil are responsible for gastro protective action. In addition to that, essential oil reduced $65 \%$ of the ulcer index [118].

For their second experiment, aspirin induced ulcer models were used. In that animals were treated with methanolic extract $(500 \mathrm{mg} / \mathrm{kg})$ and its petroleum ether insoluble fraction $(450 \mathrm{mg} / \mathrm{kg})$ and petroleum ether soluble fractions $(50,37.5,25$ and $12.5 \mathrm{mg} / \mathrm{kg})$, essential oil $(12.5 \mathrm{mg} / \mathrm{kg})$ and ranitidine $(50 \mathrm{mg} / \mathrm{kg})$. All the fractions showed significant inhibition of ulceration. Petroleum ether soluble fraction was found to be more active than essential oil and ranitidine. Thus, they concluded that constituents other than essential oil present in petroleum ether soluble fractions are also involved in the gastroprotective action. However, it significantly inhibited the ulcer formation $(71.7 \%)$ in aspirin induced gastric ulceration in Shay rats. The ulcer index $(\mathrm{mm})$ in the control and petroleum ether soluble fractions -treated rats were $1.06 \pm 0.07$ and $0.30 \pm 0.04$, respectively [118].

Finally, they were used pyloric ligation induced ulcer models treated with $\mathrm{CMC}(10 \mathrm{ml} / \mathrm{kg})$, ranitidine $(50$ $\mathrm{mg} / \mathrm{kg})$, methanolic extract $(500 \mathrm{mg} / \mathrm{kg})$ and petroleum ether soluble fractions $(50 \mathrm{mg} / \mathrm{kg})$. In that experiment they found that pretreatment with ethanolic extract (500 $\mathrm{mg} / \mathrm{kg}$ ) and petroleum ether soluble fractions $(50 \mathrm{mg} / \mathrm{kg})$ did not have any significant effect on the gastric ulcers induced by pylorus ligation. On the basis of these findings, they came to a conclusion that, gastroprotective action of 


\section{Open Access Journal of Pharmaceutical Research}

petroleum ether soluble fractions and essential oil are due to the inhibition of the overproduction of some products of the 5-lipoxygenase pathways and also due to the decrease in the gastric motility and further studies were needed to test this hypothesis [118].

\section{Hibiscus rosa-Sinensis}

H. rosa (Malvaceae) is commonly known as Shoe flower and locally known as ayamparathi, chembarathi. This plant is an annual or perennial herbaceous bush found throughout Kerala [13]. Traditionally the leaves and flowers are observed to be promoters of hair growth and aid in healing of ulcers. Flowers have been found to be effective in the treatment of arterial hypertension and to have significant antifertility effect [119]. Pharmacologically reported activities are antispermatogenic and androgenic [120] anti-tumor [121], anticonvulsant [122], anti-diabetic [123], antiulcer [124] and hair growth promoter [125]. Phytochemical constituents in this plant are anthocyanins and flavonoids, cyanidin-3,5-diglucoside, cyanidin-3-sophoroside-5glucoside, quercetin-3,7-diglucoside, quercetin-3diglucoside, a cyclopeptide alkaloid, cyanidin chloride, quercetin, hentriacontane and vitamins: riboflavin, ascorbic acid and thiamine have been reported [119].

The antiulcer activity of methanolic extract of $H$. rosa leaves was evaluated by Srivastava, et al. [124] using pylorus ligation induced ulcer model. In their experiment animals were treated with Sodium CMC, $0.3 \%$, standard drug omeprazole $(80 \mathrm{mg} / \mathrm{kg})$, methanolic extract of $H$. rosa $(200$ and $400 \mathrm{mg} / \mathrm{kg}$ ) respectively and the extracts showed a reduction in the parameters like volume of acid, free acidity, total acidity and ulcer score. The methanolic extract $(400 \mathrm{mg} / \mathrm{kg})$ showed highly significant $(\mathrm{P} \leq 0.001)$ reduction whereas, the methanolic extract $(200 \mathrm{mg} / \mathrm{kg})$ showed significant $(\mathrm{P} \leq 0.01)$ reduction in all the parameters when compared with control [124].

\section{Mangifera indica $\mathrm{L}$.}

M. indica (Anacardiaceae) commonly known as mango tree and locally known as amaram, manga, mampazham, mavu and moochi. This tree is found throughout Kerala in evergreen and semi-evergreen forests [13]. Traditionally it has been used to treat diabetes, gastric disorders, asthma, mouth sores, bleeding hemorrhoids, lung hemorrhage, anemia, nerve disorders and cough [126]. Pharmacologically reported activities include anticancer, [127] anti-inflammatory [128], antidiabetic [129], antioxidant [130], antibacterial [131], antifungal [132], anthelminthic [133], gastro protective [134], hepatoprotective [135], immunomodulatory [136], anthelmintic [137], antiviral [138] and antihyperlipemic effects [139]. Pharmacologically important compounds like mangiferin, quercetin, catechin, ellagic acid, shikimic acid, friedelin, $\alpha$-amyrin, $\beta$-amyrin, gallic acid, ferulic acid, cinnamic acid, and vanilline have been reported [126]. The antiulcer activity of ethanolic extract of $M$. indica seed kernel using acid ethanol induced ulcer model was evaluated using acid ethanol induced ulcer model by Prabhu, et al. [140]. In the study female albino rats of Wistar strains were treated with ethanolic extract of $M$. indica $(100,200$ and $400 \mathrm{mg} / \mathrm{kg}$ b.w.) for 15 days. $M$. indica seed kernel $(400 \mathrm{mg} / \mathrm{kg})$ significantly $(\mathrm{P} \leq 0.05)$ reduced the ulcer index, $\mathrm{pH}$, total acidity, $\mathrm{LPO}$ and protein levels. Percentage ulcer protection was found to be $70 \%$ and it also acted as a good antioxidant [140].

\section{Mimosa pudica $\mathrm{L}$.}

M. pudica (Fabaceae) commonly known as sensitive plant, humble plant, touch me not and locally known as theendarmani, thottalvadi, thottavadi. This is a stout stragling prostrate shrubby plant found throughout Kerala as a weed [13]. Traditionally it has been used in diseases due to corrupted blood and bile, bilious fever, piles, jaundice, leprosy, ulcers, small pox [141]. Pharmacologically reported activities are antihyperglycemic, antidiarrheal, anti-convulsant and cytotoxic [141]. The ethanolic leaf extract of $M$. pudica was evaluated in rats by using ethanol, aspirin and pylorus ligation induced ulcer models by Elango, et al. [142] M. pudica ethanolic extract $100 \mathrm{mg} / \mathrm{kg}$ body weight and ranitidine $20 \mathrm{mg} / \mathrm{kg}$ body weight for 5 days. It showed antiulcer activity in all the three models and significantly $(\mathrm{P} \leq 0.01)$ reduced the ulcer incidence when compared to the control. It also showed a decrease in gastric volume, free acidity and total acidity in the animal groups treated with ethanolic extract. From the study it has been found that M. pudica the protection against ulcerations in aspirin and ethanol induced ulcer models indicate cytoprotective action by extracts of M. pudica and anti-secretory activity of the extracts was noticed in pylorus ligation induced ulcer model [142].

Quercetin is pharmacologically important compound present in this plant, which has the power to prevent gastric mucosal lesions induced by various models (pylorus ligation, ethanol induced, cold restraint stress). It may also increase the number of natural glycoproteins, the most important proteins in the gastric mucosa, which may in turn facilitate the defence against an aggressive action and stimulates the synthesis of cyclooxygenase and local prostaglandins. Other mechanisms proposed include 


\section{Open Access Journal of Pharmaceutical Research}

inhibition of the gastric proton pump and lipoxygenase pathway, or inhibition of lipid peroxidation [142].

\section{Moringa oleifera L.}

M. oleifera (Moringaceae) commonly known as drumstick tree and locally known as muringa, moringa and sigru. This tree is found throughout Kerala [13]. Traditionally, it has been used for treating heart burn, diarrhea, malaria, diabetes, blood pressure, cholesterol, ulcer, inflammation, cold and urinary problems [143]. Pharmacologically reported activities are cardiac stimulant, anticancer [144], antiepileptic, antipyretic, wound healing [145], analgesic [146], antispasmodic [147], radioprotective [148], antioxidant and hepatoprotective [149], antihypertensive, diuretic, antidiabetic, cholesterol lowering, antibacterial, neuroprotective and antifungal [143]. Phytochemical constituents in this plant are fatty acid, protein, vitamin C, calcium, terpenoids, flavonoids, lectins, amino acids, minerals, linoleic acid, oleic acid and palmitic acid [143].

Choudhary, et al. assessed the antiulcer potential of $M$. oleifera root-bark extract in albino wistar rats using ethanol-induced and pylorus ligation-induced gastric ulceration by treating with three different doses of the extract $(150,350$, and $500 \mathrm{mg} / \mathrm{kg}$ ) for 15 consecutive days. The 350 and $500 \mathrm{mg} / \mathrm{kg}$ of M. oleifera significantly $(\mathrm{P} \leq 0.01)$ decreased the ulcer index as compared to the control group. The percentage protections against gastric ulcers were $82.58 \%, 85.13 \%$, and $86.15 \%$ at the doses of 150,350 , and $500 \mathrm{mg} / \mathrm{kg}$, respectively, in pylorus-ligated ulcer model and 55.75\%, 59.33\%, and $78.51 \%$, respectively, in ethanol-induced ulcer model. It also reduced the free acidity, total acidity, and ulcer index and increased the $\mathrm{pH}$ of gastric content compared with the control group. [150].

\section{Ocimum sanctum $\mathrm{L}$.}

O. sanctum (Lamiaceae) commonly known as basil, sacred basil, holy basil and locally known as govindapushpam, krishnathulasi, thulasi, thrithavu, karuthathrithavu. This plant is a subshurb found throughout Kerala [13]. Traditionally it has been used for common colds, headaches, stomach disorders, inflammation, heart disease, various forms of poisoning and malaria [151]. Pharmacologically reported activities are antidiabetic, hypolipdemic and antioxidant [152], cardioprotective activity [153], wound healing [154], radio-protective [155], gastroprotective [156], antimicrobial [157], immunomodulatory [158], analgesic, antipyretic and anti-inflammatory [159], sexually transmitted diseases [160], anti-fertility [161], anthelmintic [162], anticancer [163], thyroid activities [164]. Phytochemical constituents in this plant are carvacrol, caryophyllene, eugenol, linalool, urosolic acid [151].

In 2013 Bharat, et al., evaluated the antiulcer activity of aqueous and ethanolic leaf extract of tulasi in albino rats. The dose 100,200 and $400 \mathrm{mg} / \mathrm{kg}$ of 0 . sanctum has been used for the study. The aqueous and ethanolic extract of 0 . sanctum $(200 \mathrm{mg} / \mathrm{kg} \mathrm{bw})$ showed significant $(\mathrm{P} \leq 0.05)$ reduction in gastric volume, free acidity, total acidity, combined acidity and ulcer index as compared to the control group of pyloric ligations, cold restraint stress and forced swim endurance ulcer induced model and it also shown anti-secretary mechanism. This study showed that aqueous and ethanolic leaf extract of $O$. santum is effective as that of the standard synthetic drug Ranitidine [165].

\section{Piper nigrum $\mathbf{L}$.}

P. nigrum (Piperaceae) commonly known as black pepper and locally known as kurumulaku, mulakukodi, nallamulaku. It is a glabrous climber found throughout Kerala in evergreen, semi-evergreen forests and also cultivated [13]. Traditionally it is used for carminative, stimulant and stomachic [166]. Pharmacologically reported activities are antihypertensive and antiplatelets [167], antioxidant [168], antitumor and immunomodulatory [169], anti-asthmatics [170], analgesic and anticonvulsant [171], anti-inflammatory [172], anti-diarrheal [173], antispasmodic, anxiolytic, antidepressants [174], hepato-protective [175], antibacterial [176], antifungal, anti-thyroids, antiapoptotic, anti-metastatic, antimutagenic, antispermatogenic, anticolon toxin [177], insecticidal and larvicidal activities [178]. Phytochemical constituents in this plant are Phenolics, flavonoids, alkaloids, amides and steroids, lignans, neolignans, terpenes, chalcones, piperin [166]. AL-Saeed, et al. studied the effect of aqueous extract of $P$. nigrum on some physiological and histopathological parameters in aspirin induced gastric ulcer model rabbits. In the study, he was reported that the aqueous extract of $P$. nigrum showed a significant $(\mathrm{P} \leq 0.05)$ increase in $\mathrm{RBC}, \mathrm{WBC}, \mathrm{PCV}, \mathrm{Hb}$ and a significant decrease in the glucose, cholesterol and activities of AST and ALT when compared to the respective controls. Whereas aspirin and $P$. nigrum treated group showed significant reductions in $\mathrm{RBC}, \mathrm{WBC}, \mathrm{Hb}, \mathrm{PCV}$ and $\mathrm{MCHC}$ when compared to the respective controls. Moreover, treatment with aqueous extract of $P$. nigrum $(500 \mathrm{mg} / \mathrm{kg})$ for 30 days was found to be inhibiting the ulcers induced by aspirin. It prevented the increase of gastric acid 


\section{Open Access Journal of Pharmaceutical Research}

secretions, depletion of stomach wall mucus and prevented the histological changes caused by aspirin. It has been found that it might be due to the stimulation of bioenergetics processes in the gastric epithelium under the influence of $P$. nigrum [179].

\section{Phyllanthus embilica L.}

P. embilica (Phyllanthaceae) commonly known as Indian gooseberry, emblic myrobalan and locally known as nellikka, nelli, amalakam. It is a deciduous tree found in dry and moist deciduous forests, throughout the tropics of Kerala [13]. Pharmacologically reported activities are antioxidant [180], anticancer [181], antigenotoxic [182], anti-inflammatory [183], antidiabetic [184], antidepressant [185], antiulcerogenic [186], wound healing activities [187], eye disorders [188], cardiovascular diseases [189] and neurodegenerative diseases [190].

Joshi, et al. evaluated the gastric motility of $P$. embilica and Asparagas racemosus in cold stress induced gastric damage. They were compared the effect of four different formulations of $P$. emblica, namely dry powder, hot water extract, cold water extract and incinerated powder and $A$. racemosus were administered orally in the dose of 270 $\mathrm{mg} / \mathrm{kg}$ for 7 days. In case of no stress induced animals, the percentage gastric emptying for drug treated groups was $64.16 \pm 17.29,58.33 \pm 5.95,50.00 \pm 7.56$ and $64.50 \pm 16.15$ in rats treated with dry powder, hot water extract, cold water extract and incinerated powder respectively. The percentage gastric emptying of rats administered Ranitidine was $58.00 \pm 19.51 \%$, gastric emptying shown by $A$. racemosus was $76.66 \pm 5.88$, which was significantly greater than the control group. None of the P. emblica groups showed significant gastric motility changes as compared to control group and ranitidine $(\mathrm{P} \leq 0.05)$. Whereas in case of cold stress induced animal models treated with all the formulations of $P$. emblica and $A$. racemosus reversed the stress induced decrease in gastric emptying. All test groups showed improvement in percentage of gastric emptying time which was found to be statistically significant $(\mathrm{P} \leq 0.01)$ as compared to control group, hot water extract showed highest improvement in gastric emptying. Thus, they came to a conclusion that the mechanism of antiulcer activity of $P$. emblica and $A$. racemosus due to the gastric motility enhancing effect [191].

\section{Terminalia chebula Retz.}

T. chebula (Combretaceae) commonly known as gallnut, black myrobalan, and chebulic myrobalan and locally known as kadukka, pulicakku, putanam. It is a deciduous tree found in dry and moist deciduous forests of Idukki, Thiruvananthapuram, Kozhikode, Wayanad, and Palakad districts of Kerala [13]. Traditionally, it has been used for treating constipation, diarrhea, ulcers, gastroenteritis, asthma, cough, dyspnea, dyspepsia, hemorrhoids, candidiasis, parasites, malabsorption syndrome, hepatomegaly, vesicular and renal calculi, urinary discharges, tumors, skin diseases, leprosy, intermittent fever, rheumatism, arthritis, gout, neuropathy, paralysis, memory loss, epilepsy, depression, diabetes, cardiovascular diseases, anorexia and wounds [192]. Pharmacologically reported activities are antibacterial, antifungal, antiviral, anticarcinogenic, antioxidant, adaptogenic and antianaphylactic, hypolipidemic, hepatoprotective, cardio protective, antidiabetic, wound healing, antiulcer, immunomodulatory and chemo preventive [193]. The antiulcer activity of methanolic extract of $T$. chebula fruits was evaluated in wistar rats by using pylorus ligation and ethanol induced ulcer models by Raju, et al. [192]. It has been found that in both models the extract $(250 \mathrm{mg} / \mathrm{kg}$ and $500 \mathrm{mg} / \mathrm{kg}$ ) shown a significant $(\mathrm{P} \leq 0.01)$ reduction in gastric volume, free acidity and ulcer index as compared to control. In pyloric ligation induced ulcer model the protection index was found to be $76 \%$ and $82 \%$ at the dose of 250 and $500 \mathrm{mg} / \mathrm{kg}$ in comparison to control and the omeprazole reference standard drug shown $84 \%$ reduction of ulcer. Where as in ethanol induced ulcer model methanolic extract of $T$. chebula has shown significant protection index of $54 \%$ and $66 \%$ with the dose of 250 and $500 \mathrm{mg} / \mathrm{kg}$ respectively in comparison to control, omeprazole (standard drug) showed ulcer reduction by $72 \%$. Finally, they concluded that T. chebula fruit extract have potential antiulcer activity in the both models. These results may further suggest that methanolic extract was found to possess antiulcerogenic as well as ulcer healing properties, which might be due to its antisecretory activity [192].

\section{Zingibera officinalis Roscoe.}

Z. officinalis (Zingiberaceae) commonly known as ginger and locally known as andrakam, chukku, erukizhangu, inchi. It is a rhizomatous herb found throughout Kerala [13]. Traditionally it is used for nausea, vomiting, asthma, cough, palpitaion, inflammation, dyspepsia, loss of appetite, constipation, indigestion and pain [194]. Pharmacologically reported activities are antioxidant and antimicrobial [195], anticancer [196], antidiabetic [197], anti-inflammatory [198], analgesic [199], antipyretic [200], immunomodulatory [201], antiplatelet aggregation [202], antiangiogenic [203], hepatoprotective [204], antiemetic [205], neuroprotective [206], 


\section{Open Access Journal of Pharmaceutical Research}

anthelmintic [207], gastro protective [208] and cardiovascular [209]. Terpenes, alcohols, ketones, flavonoids, carotenoids, gingeroles, phytoestrogens and vitamin $C$ are the phytochemical constituents present in it [194]. In 2014, the anti-ulcerogenic effect of $Z$. officinale (Ginger) roots in rats was evaluated by Uz Zaman, et al. using indomethacin induced gastric damage [210]. The ginger roots extract (200 and $400 \mathrm{mg} / \mathrm{kg}$ ) significantly
$(\mathrm{P} \leq 0.001)$ inhibited the gastric damage induced by indomethacin. The percentage inhibition of gastric ulcers was $40.91 \%, 57.58 \%$ and $65.91 \%$ by 200 and $400 \mathrm{mg} / \mathrm{kg}$ of $Z$. officinalis and omeprazole respectively. The 400 $\mathrm{mg} / \mathrm{kg}$ of aqueous extract of $Z$. officinalis was found to be more effective than $200 \mathrm{mg} / \mathrm{kg}$. The ginger roots extract has the potential to prevent the gastric damage resulting from indomethacin (NSAID) administration [210].

\begin{tabular}{|c|c|c|c|}
\hline Plant & $\begin{array}{c}\text { Dose } \\
(\mathrm{mg} / \mathrm{kg})\end{array}$ & Standard & Mechanism of action \\
\hline Acacia nilotica & $\begin{array}{l}100 \text { and } \\
200\end{array}$ & $\begin{array}{c}\text { Cimetidine } 10 \\
\mathrm{mg} / \mathrm{kg}\end{array}$ & $\begin{array}{c}\text { Antisecretory, mucosal defence mechanism, reduce gastric } \\
\text { motility, antioxidant [28] }\end{array}$ \\
\hline Achyranthes aspera & $\begin{array}{c}200,400 \\
600\end{array}$ & $\begin{array}{c}\text { Omeprazole } 10 \\
\mathrm{mg} / \mathrm{kg}\end{array}$ & Antisecretory and antioxidant [29] \\
\hline Aegle marmelose & $\begin{array}{l}200 \text { and } \\
400\end{array}$ & \begin{tabular}{|c|}
$\begin{array}{c}\text { Omeprazole } 20 \\
\mathrm{mg} / \mathrm{kg}\end{array}$ \\
\end{tabular} & Cytoprotective [42] \\
\hline Allilum sativum & $\begin{array}{l}200,300 \\
\text { and } 400\end{array}$ & $\begin{array}{c}\text { Ranitidine } 50 \\
\mathrm{mg} / \mathrm{kg}\end{array}$ & $\begin{array}{c}\text { Antioxidant, anti-inflammatory, immune cell modulatory and } \\
\text { calcium modulatory actions [53] }\end{array}$ \\
\hline Aloe vera & 200 & $\begin{array}{c}\text { Omeprazole } 20 \\
\mathrm{mg} / \mathrm{kg}\end{array}$ & $\begin{array}{l}\text { Cytoprotective, [60] anti-inflammatory, [211] gastric mucus } \\
\text { production, [60] antioxidant, [60] anti secretary, [60] }\end{array}$ \\
\hline Annona muricata & $\begin{array}{c}50,100,200 \\
\text { and } 400\end{array}$ & $\begin{array}{c}\text { Omeprazole } 30 \\
\mathrm{mg} / \mathrm{kg}\end{array}$ & $\begin{array}{l}\text { By mediating the synthesis of prostaglandins, [73] decreases the } \\
\text { gastric secretion and motility and increases blood flow [212] }\end{array}$ \\
\hline \multirow[b]{2}{*}{ Bacopa monneri } & \multirow{2}{*}{$\begin{array}{l}200 \text { and } \\
400\end{array}$} & \multirow{2}{*}{$\begin{array}{c}\text { Omeprazole } 20 \\
\mathrm{mg} / \mathrm{kg}\end{array}$} & Cytoprotective, \\
\hline & & & $\begin{array}{l}\text { Antioxidant, spasmolytic, increase gastric mucosal production, , } \\
\text { increases prostaglandin production [82] }\end{array}$ \\
\hline \multirow{2}{*}{ Carica papaya } & \multirow{2}{*}{$\begin{array}{l}250 \text { and } \\
500\end{array}$} & \multirow{2}{*}{\begin{tabular}{|c|} 
Rabeprazole 20 \\
$\mathrm{mg} / \mathrm{kg}$
\end{tabular}} & Antisecretory, [98] \\
\hline & & & Cytoprotective, [96] \\
\hline \multirow{2}{*}{ Centella asiatica } & \multirow{2}{*}{$\begin{array}{l}100,200 \\
\text { and } 400\end{array}$} & \multirow{2}{*}{$\begin{array}{c}\text { Omeprazole } 20 \\
\mathrm{mg} / \mathrm{kg}\end{array}$} & Antioxidant, anti-inflammatory, \\
\hline & & & reduction in gastric motility, $[106]$ \\
\hline $\begin{array}{l}\text { Curcuma longa } \\
\text { (curcumin) }\end{array}$ & $\begin{array}{l}5,10,20,40 \\
80 \text { and } 100\end{array}$ & $\begin{array}{c}\text { Omeprazole } 20 \\
\mathrm{mg} / \mathrm{kg}\end{array}$ & $\begin{array}{l}\text { Antisecretory, cytoprotective, antioxidant, and anti-inflammatory } \\
{[116]}\end{array}$ \\
\hline Elatoria cardamom & $\begin{array}{l}100,300 \\
\text { and } 500\end{array}$ & $\begin{array}{c}\begin{array}{c}\text { Ranitidine } 50 \\
\mathrm{mg} / \mathrm{kg}\end{array} \\
\end{array}$ & $\begin{array}{c}\text { Decrease in gastric motility and inhibition of production of some } \\
\text { products of 5-lipoxygenase pathway [118] }\end{array}$ \\
\hline \multirow{5}{*}{ Embilica officinalis } & \multirow{5}{*}{270} & \multirow{5}{*}{$\begin{array}{l}\text { Ranitidine } \\
27 \mathrm{mg} / \mathrm{kg}\end{array}$} & $\begin{array}{l}\text { It deceased the gastric motility there by decreased the gastric } \\
\text { erosions, [191] }\end{array}$ \\
\hline & & & Decrease in the acid and pepsin secretion (antisecretory activity), \\
\hline & & & $\begin{array}{l}\text { Increase in the secretion of mucosal protective factors. Mucus } \\
\text { secreted from the mucus neck cells covers the gastric mucosa } \\
\text { thereby preventing physical damage and back diffusion of } \\
\text { hydrogen ions [213] }\end{array}$ \\
\hline & & & $\begin{array}{l}\text { It acts as antioxidant by decreasing the gastric peroxidase activity } \\
\text { and it could be due to the presence of Emblicanin A and B in its } \\
\text { extract. [213] }\end{array}$ \\
\hline & & & cytoprotective action \\
\hline Hibiscus rosa-sinensis & $\begin{array}{l}200 \text { and } \\
400\end{array}$ & $\begin{array}{c}\text { Omeprazole } 80 \\
\mathrm{mg} / \mathrm{kg}\end{array}$ & Anti secretary activity [124] \\
\hline \multirow{3}{*}{ Mangifera indica } & \multirow{3}{*}{$\begin{array}{l}100,200 \\
\text { and } 400\end{array}$} & \multirow{3}{*}{$\begin{array}{c}\text { Ranitidine } 32 \\
\mathrm{mg} / \mathrm{kg}\end{array}$} & Antisecretory activity [140] \\
\hline & & & Cytoprotective action by increasing the mucus secretion. [214] \\
\hline & & & gastroprotective properties in an experimental rat model by \\
\hline
\end{tabular}




\section{Open Access Journal of Pharmaceutical Research}

\begin{tabular}{|c|c|c|c|}
\hline & & & reducing gastric juice volume and acidity. [215] \\
\hline \multirow{5}{*}{ Mimosa pudica } & \multirow{5}{*}{100} & \multirow{5}{*}{$\begin{array}{l}\text { Ranitidine } 20 \\
\mathrm{mg} / \mathrm{kg}\end{array}$} & Cytoprotective \\
\hline & & & Antisecretory \\
\hline & & & Antiulcer activity is due to the flavonoids and quercetin. \\
\hline & & & $\begin{array}{l}\text { Quercetin may increase the amount of natural glycoproteins, the } \\
\text { most important proteins in the gastric mucosa, which may in turn } \\
\text { facilitate the defence against an aggressive action. }\end{array}$ \\
\hline & & & $\begin{array}{l}\text { Quercetin also stimulates the synthesis of cyclooxygenase and of } \\
\text { local prostaglandins. [142] }\end{array}$ \\
\hline \multirow{3}{*}{ Muringa oleifera } & \multirow{3}{*}{$\begin{array}{l}150,350 \\
\text { and } 500\end{array}$} & \multirow{3}{*}{$\begin{array}{l}\text { Omeprazole } 30 \\
\mathrm{mg} / \mathrm{kg}\end{array}$} & Cytoprotective \\
\hline & & & Antisecretory \\
\hline & & & Increased mucus secretion [150] \\
\hline \multirow{2}{*}{ Ocimum santum } & \multirow{2}{*}{$\begin{array}{l}100,200 \\
\text { and } 400\end{array}$} & \multirow{2}{*}{$\begin{array}{l}\text { Ranitidine } 20 \\
\mathrm{mg} / \mathrm{kg}\end{array}$} & Antisecretory \\
\hline & & & Cytoprotective [165] \\
\hline \multirow{3}{*}{ Piper nigum } & \multirow{3}{*}{500} & & Inhibition of gastric motor activity \\
\hline & & & Stimulation of prostaglandin synthesis \\
\hline & & & Mucosal defence mechanism [179] \\
\hline \multirow{2}{*}{ Terminalia chebula } & \multirow{2}{*}{$\begin{array}{l}250 \text { and } \\
500\end{array}$} & \multirow{2}{*}{$\begin{array}{l}\text { Omeprazole } \\
20 \mathrm{mg} / \mathrm{kg}\end{array}$} & Antisecretory \\
\hline & & & Cytoprotective [192] \\
\hline \multirow{3}{*}{ Zingibera officinalis } & \multirow{3}{*}{$\begin{array}{l}200 \text { and } \\
400\end{array}$} & \multirow{3}{*}{$\underset{\mathrm{mg} / \mathrm{kg}}{\text { Omeprazole } 10}$} & 5-lipoxygenase inhibitory effect, [210] \\
\hline & & & Antisecretory [216] \\
\hline & & & Increased mucin secretion [217] \\
\hline
\end{tabular}

Table 1: Antiulcer plants from Kerala.

\section{Discussion and Conclusion}

Alkaloids, flavonoids, terpenoids, tannins, glycosides, terpines, and resins are the vital plant compounds with promising antiulcer activities. Evidences from various scientific literatures shows that, these compounds are active against different ulcer models like pylorus-ligation, ethanol, stress, aspirin, indomethacin, phenylbutazone, histamine and cysteamine induced ulcers. Most of these compounds possess distinct mechanisms of antiulcer activities. The predominant features of these plant derived compounds are fewer side effects, easy availability as well as low cost. The compounds work by blocking the receptors or synthesis and release of hormones like histamine, gastrin and neurotransmitter acetylcholine, which are the major stimulators of gastric acid secretion. Whereas, some other compounds increases the synthesis and release of somatostatin and prostaglandin E2 and I2, there by which inhibits acid secretion. The drugs of plant origin work on the pathway involved in the course of acid secretion i.e., gastrin secreted from G-cells of gastric antrum activate CCK2 receptor in the enterochromaffin-like cells results in histamine release and it acts on the parietal cell histamine $(\mathrm{H} 2)$ receptors to elevate cAMP that stimulates the proton pump acid secretion. $\mathrm{H}+\mathrm{K}+\mathrm{ATPase}$ is a symport carrier proton pump involved in the last stage of acid secretion in to the lumen. Secondary metabolites having potent antisecretory activity may works by blocking these proton pump present in the parietal cells. Therefore, its inhibitors have a major role in arresting ulcer formation [218]. In addition to that, direct vagal stimulation also provoke acid secretion by acetylcholine, which stimulates the M3 receptors on the parietal cells. Furthermore, somatostatin released from the D-cells of the stomach acts on the somatostatin (SST2) receptor and inhibit the release of gastrin and histamine as well as the parietal cell acid output. NSAIDS, alcohol, coffee, smoking, spicy foods, stress etc. are some factors that can worse the ulcer condition [218].

Several alkaloids have been identified in plants, of these imidazole, non-nitrogen heterocycle, phenylalkylamine, piperidine, pyrazine, pyridine, pyrrolidine, pyrrolizidine, quinolizidine, and steroidal alkaloids are found to be active against various ulcer models. The most interesting fact is that, different alkaloids possess distinct mechanisms of antiulcer activities. Tropane alkaloids possess antisecretory and antispasmodic activities, which is due to its antimuscarinic action. Whereas pyridine alkaloids have antinicotinic action, which decreases the hemorrhage and increases the $\mathrm{pH}$ gradient/gastric fluid volume. In contrast, quinolizidine alkaloids found to be decreases the 


\section{Open Access Journal of Pharmaceutical Research}

acid secretion and gastric motility. Piperine belonging to the piperidine alkaloid decreases the volume of gastric juice, gastric acidity, and pepsin-A activity. However, cytoprotective nature of steroidal alkaloid is due to increase in free mucus and prostaglandin levels. It also showed a reduction of exfoliation of superficial cells, hemorrhages and blood cell infiltration due to the increase in gastrin secretion and mRNA expression of epidermal growth factors [219].

Tannins are a class of complex biomolecules of polyphenolic nature react with the proteins of the tissue layers and precipitate micro proteins at the site of the peptic ulcer, which forms a protective covering that prevents absorption of toxic substances, and promote resistance to the action of proteolytic enzymes, an associated activity against Helicobacter pylori. Gallic acid and ellagic acid are the hydrolysis products of hydrolysable tannins which demonstrated promising antibacterial activity against Helicobacter pylori. In addition to that, ellagic acid exhibited antisecretory activity, it is due to the competitive inhibition of gastric $\mathrm{H}^{+}$, $\mathrm{K}^{+}$-ATPase, and proposed that ellagic acid may compete with ATP at the ATP hydrolysis site, thus markedly inhibiting acid secretion, and stress-induced gastric lesions. Tannic acid also possesses enzyme inhibitory activity. In several experimental models of gastric ulcer, purified tannins have shown to be involved in gastrointestinal tract anti-inflammatory actions, promotion of tissue repair, acid secretion inhibition, and to present both antioxidant and anti-Helicobacter pylori activity [220].

The essential oil acts generally by stimulating the prostaglandins which is responsible for maintaining the integrity of the gastric mucosa by stimulating mucus and bicarbonate secretion and nitric oxide appears to be a major regulator of blood flow and gastric microcirculation. Endogenous prostaglandins act as activators of KATP channels, and this mechanism, at least in part, mediates gastroprotection in rats [221].

Flavonoids protect the gastrointestinal mucosa from lesions produced by various experimental ulcer models and against different necrotic agents. Several mechanisms of action may be involved in this protective effect. The antioxidant mechanism of flavonoids, especially garcinol, rutin and quercetin, is mainly due to the presence of an odihydroxy group in the B ring (catechol), and also due to the presence of 2,3 double bond in conjugation with a 4oxo function, as well as the presence of hydroxyl groups in positions 3, 5 and 7 . In addition to the free radicle scavenging activity they also possess transition metal ions chelation, inhibition of oxidizing enzymes, increase of proteic and nonproteic antioxidants and reduction of lipid peroxidation. More over quercetin has an anti-secretory mechanism of action. Whereas, the flavonols has antihistaminic properties, thus, decreases histamine levels, as well as preventing the release of histamine from gastric mast cells and inhibiting the gastric $\mathrm{H}+/ \mathrm{K}+$ proton pump, diminishing acid gastric secretion. On the other hand, chalcones with more than one isoprenyloxyl group, possess cytoprotective effects, which increases the mucosal blood flow, stimulate the synthesis of mucosubstances in the gastric mucosa and increase PGs levels like essential oils [222].

From this review, it is clear that, Kerala is a rich source of medicinal plants having antiulcer properties. Alkaloids, flavonoids, terpenoids, tannins, glycosides, terpenes, and resins are the vital plant compounds responsible for this activity. Although, the results of this study revealed that the plant extract of several medicinal plants have good potential for use in peptic ulcer disease. It is evident that experimental evaluation of herbal drugs for the treatment of gastric ulcer is rather promising but very few have reached clinical trials and still few have been marketed. This shows that the benefits of research are not reaching the people. Hence, pharmacologists need to take more interest in evaluation of herbal drugs for potential antiulcer activity and standardization of such herbal drugs to be clinically effective and globally competitive.

\section{References}

1. Barazandeh F, Yazdanbod A, Pourfarzi F, Sepanlou SG, Derakhshan MH, et al. (2012) Epidemiology of peptic ulcer disease: endoscopic results of a systematic investigation in Iran. Middle East J Dig Dis 4(2): 9096.

2. Khomenko T, Szabo S, Deng X, Ishikawa H, Anderson GJ, et al. (2009) Role of iron in the pathogenesis of cysteamine-induced duodenal ulceration in rats. Am J Physiol Gastrointest Liver Physiol 296(6): G1277G1286.

3. Vyawahare NS, Deshmukh VV, Godkari MR, Kagathara VG (2009) Plants with anti-ulcer activity. Pharmacogn Rev 3: 108-115.

4. Brooks FP (1985) The pathophysiology of peptic ulcer disease. Dig Dis Sci 30(11): 15S-29S.

5. Zapata-Colindres JC, Zepeda-G omez S, Montano LA, Vasquez-Ballesteros E, Villalobos J, et al. (2006) The association of Helicobacter pylori infection and 


\section{Open Access Journal of Pharmaceutical Research}

nonsteroidal anti-inflammatory drugs in peptic ulcer disease. Can J Gastroenterol 20(4): 277-280.

6. Lau JY, Sung Y, Hill C, Henderson C, Howden CW, et al. (2011) Systematic review of the epidemiology of complicated peptic ulcer disease: incidence, recurrence, risk factors and mortality. Digestion 84(2): 102-113.

7. India: Peptic Ulcer Disease.

8. Hoogerwerf WA, Pasricha PJ (2011) Agents Used for Control of Gastric Acidity and Treatment of Peptic Ulcers and Gastro Esophageal Reflux Disease editions, $10^{\text {th }}$ (Edn.), McGraw-Hill, New York, NY, USA, pp: 1005-1019.

9. Lima Z, Severi JA, Pellizon CH, Brito AR, Solis PN, et al. (2006) Can the aqueous decoction of mango flowers be used as an antiulcer agent?. J Ethanopharmacol 106(1): 29-37.

10. Harold K, Grant Denis M, Mitchel J (2012) Principles of Medical Pharmacology 7: 557-559.

11. Borelli F, Izzo A (2000) The plant kingdom as a source of anti-ulcer remedies. Phytother Res 14(8): 581-591.

12. Nascimento GF, Locatelli J, Freitas PC, Silva GL (2000) Antibacterial activity of plant extracts and phytochemicals on antibiotic resistant bacteria. Braz J Microbiol 31(4): 247-256.

13. Kerala Plants.

14. Luqman RJ, Shahid-ul-Islam, Faqeer M (2015) Acacia nilotica (L.): A review of its traditional uses, phytochemistry, and pharmacology. Sustainable Chem Pharm 2: 12-30.

15. Dafallah AA, Al-Mustafa Z (1996) Investigation of the anti-inflammatory activity of Acacia nilotica and Hibiscus sabdariffa. Am J Chin Med 24(3-4): 263-269.

16. Sultana B, Anwar F, Przybylski R (2007) Antioxidant activity of phenolic components present in barks of Azadirachta indica, Terminalia arjuna, Acacia nilotica, and Eugenia jambolana Lam. Trees. Food Chem 104(3): 1106-1114.

17. Misar A, Bhagat R, Mujumdar AM (2008) Antidiarrhoeal activity of Acacia nilotica Wild. Bark methanol extract. Hindustan Antibiot Bull 50: 14-20.
18. Gilani AH, Shaheen F, Zaman M, Janbaz KH, Shah BH, et al. (1999) Studies on antihypertensive and antispasmodic activities of methanol extract of Acacia nilotica pods. Phytother Res 13(8): 665-669.

19. Rani P, Khullar N (2004) Antimicrobial evaluation of some medicinal plants for their anti-enteric potential against multi-drug resistant Salmonella typhi. Phytother Res 18(8): 670-673.

20. Hostel H, Jackson F, Athanasiadou S, Thamsborg SM, Hoskin SO (2006) The effects of tannin-rich plants on parasitic nematodes in ruminants. Trends Parasitol 22(6): 253-261.

21. Hamza OJM, Mikx FHM, Selemani AO, Mbwambo ZH, Vander Ven AJAM, et al. (2006) Antifungal activity of some Tanzanian plants used traditionally for the treatment of fungal infections. J Ethnopharmacol 108(1): 124-132.

22. Shah BH, Safdar B, Virani SS, Nawaz Z, Saeed SA, et al. (1997) The antiplatelet aggregatory activity of Acacia nilotica is due to blockade of calcium influx through membrane calcium channels. Gen Pharmacol Vasc Syst 29(2): 251-255.

23. Alli LA, Nafiu MO, Adesokan AA, Akanji MA, Tijani AY, et al. (2014) Antipyretic and analgesic activities of aqueous extract of Acacia nilotica root. Biokemistri 26(4): 55-62.

24. Asres K, Seyoum A, Veeresham C, Buca F, Gibbons S (2005) Naturally derived anti-HIV agents. Phytother Res 19(7): 557-581.

25. Meena PD, Kaushik P, Shukla S, Soni AK, Kumar M, et al. (2006) Anticancer and antimutagenic properties of Acacia nilotica (Linn.) on 7, 12 -Di-methyl benz(a)anthracene-induced skin papilloma genesis in Swiss Albino Mice. Asian Pac J Cancer Prev 7(4): 627632.

26. Asad M, Munir TA, Afzal N (2011) Acacia Nilotica leaves extract and glyburide: comparison of fasting blood glucose, serum insulin, $\beta$-thromboglubulin levels and platelet aggregation in streptozotocin induced diabetic rats. J Pak Med Assoc 61(3): 247251.

27. Eldeen IMS, Elgorashi EE, Staden JV (2005) Antibacterial, antiinflammatory, anti-cholinesterase and mutagenic effects of extracts obtained from some trees used in South African traditional medicine. J Ethnopharmacol 102(3): 457-464. 


\section{Open Access Journal of Pharmaceutical Research}

28. Vijay KB, Rajesh KG (2012) Gastroprotective effect of Acacia nilotica young seedless pod extract: Role of polyphenolic constituents. Asian Pac J Tropical Medicine 5(7): 523-528.

29. Ashish KD, Papiya B, Neelesh KV, Rana AC (2012) Gastroprotective effect of Achyranthes aspera Linn. leaf on rats. Asian Pac J Tropical Medicine 5(3): 197 201.

30. Barua CC, Talukdar A, Begum SA, Lahon LC, Sharma DK, et al. (2010) Antinociceptive activity of methanolic extract of leaves of A. aspera Linn. in animal model of nociception. Indian J Exp Biol 48(8): 817-821.

31. Baliga MS, Bhat HP, Joseph N, Fazal F (2011) Phytochemistry and medicinal uses of the bael fruit (Aegle marmelos Correa): a concise review. Food Res Int 44(7): 1768-1775.

32. Bikash M, Keshav RP, Biraj S, Rajendra K (2018) Phytochemical profile and pharmacological activity of Aegle marmelos Linn. J Integr Med 16(3): 153-163.

33. Reddy VP, Urooj A (2013) Antioxidant properties and stability of Aegle marmelos leaves extracts. J Food Sci Technol 50(1): 135-140.

34. Khan TH, Sultana S (2009) Antioxidant and hepatoprotective potential of Aegle marmelos Correa. against CCl4-induced oxidative stress and early tumor events. J Enzyme Inhib Med Chem 24(2): 320-327.

35. Seema PV, Sudha B, Padayatti PS, Abraham A, Raghu KG, et al. (1996) Kinetic studies of purified malate dehydrogenase in liver of streptozotocin-diabetic rats and the effect of leaf extract of Aegle marmelose (L.) Correa ex Roxb. Indian J Exp Biol 34(6): 600-602.

36. Panda S, Kar A (2009) Periplogenin-3-0--Dglucopyranosyl-( $1 \rightarrow 6)--D$-glucopyaranosyl--(1 $\rightarrow 4)$-Dcymaropyranoside, isolated from Aegle marmelos protects doxorubicin induced cardiovascular problems and hepatotoxicity in rats. Cardiovasc Ther 27(2): 108-116.

37. Arul V, Miyazaki S, Dhananjayan R (2005) Studies on the anti-inflammatory, antipyretic and analgesic properties of the leaves of Aegle marmelos Corr. J Ethnopharmacol 96(1-2): 159-163.

38. Singh P, Kumar A, Dubey NK, Gupta R (2009) Essential oil of Aegle marmelos as a safe plant-based antimicrobial against post-harvest microbial infestations and aflatoxin contamination of food commodities. J Food Sci 74(6): M302-M307.

39. Mishra BB, Kishore N, Tiwari VK, Singh DD, Tripathi V (2010) A novel antifungal anthraquinone from seeds of Aegle marmelos Correa (family Rutaceae). Fitoterapia 81(2): 104-107.

40. Narender T, Shweta S, Tiwari P, Papi RK, Khaliq T, et al. (2007) Antihyperglycemic and antidyslipidemic agent from Aegle marmelose. Bio Org Med Chem Lett 17(6): 1808-1811.

41. Lampronti I, Martello D, Bianchi N, Borgatti M, Lambertini, et al. (2003) In vitro antiproliferative effects on human tumor cell lines of extracts from the Bangladeshi medicinal plant Aegle marmelos Correa. Phytomed 10(4): 300-308.

42. Sharmin R, Mohammad RQ, Rayhana S, Azmary M, Khaleda S, et al. (2016) Evaluation of Anti-Ulcer Activity of Ethanolic Extract of Aegle Marmelos Leaves on Rats. ARC J Dental Sci 1: 23-26.

43. Prasan R, Bhandari (2012) Garlic (Allium sativum L.): A review of potential therapeutic applications. Int J Green Pharm 6(2): 118-129.

44. Borek C (2006) Garlic reduces dementia and heartdisease risk. J Nutr 136(3 Suppl): 810S-812S.

45. Al-Qattan KK, Khan I, Alnaqeeb MA, Ali M (2003) Mechanism of garlic (Allium sativum) induced reduction of hypertension in $2 \mathrm{~K}-1 \mathrm{C}$ rats: A possible mediation of $\mathrm{Na} / \mathrm{H}$ exchanger isoform - 1. Prostaglandins Leukot Essent Fatty Acids 69(4): 217222.

46. Brankovic S, Radenkovic M, Kitic D, Veljkovic S, Ivetic $\mathrm{V}$, et al. (2011) Comparison of the hypotensive and bradycardic activity of ginkgo, garlic, and onion extracts. Clin Exp Hypertens 33(2): 95-99.

47. Budoff M (2006) Aged garlic extract retards progression of coronary artery calcification. J Nutr 136(3 Suppl): 741S-744S.

48. Ahmad MS, Ahmed N (2006) Antiglycation properties of aged garlic extract: Possible role in prevention of diabetic complications. J Nutr 136(3): 796S-799S.

49. Milner JA (2001) A historical perspective on garlic and cancer. J Nutr 131(3s): 1027S-1031S. 


\section{Open Access Journal of Pharmaceutical Research}

50. Borek C (2001) Antioxidant health effects of aged garlic extract. J Nutr 131(3s): 1010S-1015S.

51. Cruz C, Correa-Rotter R, Sanchez-Gonzalez DJ, Hernández-Pando R, Maldonado PD, et al. (2007) Renoprotective and antihypertensive effects of Sallylcysteine in 5/6 nephrectomized rats. Am J Physiol Renal Physiol 293(5): 1691-1698.

52. Kyo E, Uda N, Kasuga S, Itakura Y (2001) Immunomodulatory effects of aged garlic extract. J Nutr 131(3s): 1075S-1079S.

53. Arunachalam M, Shailja S, Krishnan S (2014) Ameliorative effects of Allilum sativum in pyloric ligation induced peptic ulcer in rat. Pharmacologia 5(7): 256-262.

54. West DP, Zhu YF (2003) Evaluation of Aloe vera gel gloves in the treatment of dry skin associated with occupational exposure. Am J Infect Control 31(1): 4042.

55. Madan J, Sharma AK, Inamdar N, Rao HS, Singh R (2008) Immunomodulatory properties of Aloe vera gel in mice. Int J Green Pharm 2(3): 152-154.

56. Heggers JP, Pineless GR, Robson MC (1979) Dermaide aloe/Aloe vera gel: Comparison of the antimicrobial effects. Am J Med Tech 41: 293-294.

57. Sydiskis RJ, Owen DG, Lohr JL, Rosler KH, Blomster RN (1991) Inactivation of enveloped viruses by anthraquinones extracted from plants. Antimicrob Agents Chemother 35(12): 2463-2466.

58. Stanic S (2007) Anti-genotoxic effect of Aloe vera gel on the mutagenic action of ethyl methanesulfonate. Arch Biol Sci 59(3): 223-226.

59. Rajasekaran S, Ravi K, Sivagnanam K, Subramanian S (2006) Beneficial effects of Aloe vera leaf gel extract on lipid profile status in rats with streptozotocin diabetes. Clin Exp Pharmacol Physiol 33(3): 232-237.

60. Sai KB, Radha KL, Gowrinath RM (2011) Anti-ulcer effect of Aloe vera in non-steroidal anti-inflammatory drug induced peptic ulcers in rats. Afr J Pharm Pharmacol 5(16): 1867-1871.

61. Moghadamtousi SZ, Fadaeinasab M, Nikzad S, Mohan G, Ali HM, et al. (2015) Annona muricata (Annonaceae): a review of its traditional uses, isolated acetogenins and biological activities. Int J Mol Sci 16(7): 15625-15658.
62. Solomon W (2014) Phytochemical screening and antimicrobial activities of Annona muricata (L.) leaf extract. Am J Biol Chem Pharm Sci 2(1): 1-7.

63. Sousa OV, Vieira GDV, de Jesus RG, de Pinho J, Yamamoto CH, et al. (2010) Antinociceptive and antiinflammatory activities of the ethanol extract of Annona muricata L. leaves in animal models. Int J Mol Sci 11(5): 2067-2078.

64. Luna JS, Dos Santos AF, De Lima MRF, De Omena MC, De Mendonc FC, et al. (2005) A study of the larvicidal and molluscicidal activities of some medicinal plants from northeast Brazil. J Ethnopharmacol 97(2): 199206.

65. Alitonou GA, Tchobo FP, Sessou P, Avlessi F, Menut C, et al. (2013) Chemical composition, antiradical and anti-inflammatory activities of four annonaceae from Benin. Int J Pharm Chem Biol Sci 3(3): 914-923.

66. Oviedo V, Garcia M, Diaz C, Marder M, Costa M, et al. (2009) Extracto y fraccio' n alcaloidal de Annona muricata con actividad de tipo ansiolı'tica en ratones. Rev Colomb Cienc Quım Farma 38(1): 105-120.

67. Hamizah S, Roslida AH, Fezah O, Tan KL, Tor YS, et al. (2012) Chemopreventive potential of Annona muricata L. leaves on chemically-induced skin papilloma genesis in mice. Asian Pac J Cancer Prev 13(6): 2533-2539.

68. Roslida AH, Chan PF, Zuraini A, Mohd KH, (2012) Antinociceptive and anti-ulcerogenic activities of the ethanolic extract of Annona muricata leaf. Brazilian J Pharmacogn 22(3): 1-12.

69. Padmaa MP, Chansouria JPN, Khosa RL (2009) Wound healing activity of Annona muricata extract. J Pharm Res 2(3): 404-406.

70. Arthur FK, Woode E, Terlabi E, Larbie C (2012) Bilirubin lowering potential of Annona muricata (Linn.) in temporary jaudiced rats. Am J Pharmacol Toxicol 7(2): 33-40.

71. Adewole SO, Caxton-Martins EA (2006) Morphological changes and hypoglycemic effects of Annona muricata Linn. (Annonaceae) leaf aqueous extract on pancreatic $\beta$-cells of Streptozotocin-treated diabetic rats. Afr J Biomed Res 9: 173-187.

72. Nwokocha CR, Owu DU, Gordon A, Thaxter K, McCalla G, et al. (2012) Possible mechanisms of action of the hypotensive effect of Annona muricata (soursop) in 


\section{Open Access Journal of Pharmaceutical Research}

normotensive Sprague-Dawley rats. Pharm Biol 50(11): 1436-1441.

73. Elizangela BB, Francisco EBJ, Dayanne RO, Cicera NF, Gyllyandeson AD, et al. (2018) Antiulcerogenic activity of the hydroalcoholic extract of leaves of Annona muricata Linnaeus in mice. Saudi J Bio Sci 25(4): 609-621.

74. Kashmira JG, Jagruti AP (2010) A review on Bacopa monniera: Current research and future prospects. Int J Green Pharm 4(1): 1-9.

75. Sinha MM (1971) Some empirical behavioural data indicative of concomitant biochemical reactions. Proceeds Ind Sci Congress Part II pp: 1-26.

76. Bhattacharya SK, Kumar A, Ghosal S (1999) Effect of Bacopa monnieri on animal models of Alzheimer's disease and perturbed central cholinergic markers of cognition in rats. Mol Aspects Asian Med pp: 27-58.

77. Tripathi YB, Chaurasia S, Tripathi E, Upadhyay A, Dubey GP (1996) Bacopa monniera Linn. as an antioxidant: mechanism of action. Ind J Exp Biol 34(6): 523-526.

78. Sairam K, Dorababu M, Goel RK, Bhattacharya SK (2002) Antidepressant activity of standardized extract of Bacopa monniera in experimental models of depression in rats. Phytomed 9(3): 207-211.

79. Martis G, Rao A, Karanth K.S (1992) Neuropharmacological activity of Herpestis monniera. Fitoterapia 63: 399-404.

80. Rai D, Bhatia G, Palit G, Pal R, Singh S, et al. (2003) Adaptogenic effect of Bacopa monniera (Brahmi). Pharmacol Biochem Behav 75(4): 823-830.

81. Yadav SK, Jain AK, Tripathi SN, Gupta JP (1989) Irritable bowel syndrome: therapeutic evaluation of indigenous drugs. Ind J Med Res 90: 496-503.

82. Rubaba K, Ashfia FK, Sabiha A, Najia SS, Maliha TM, et al. (2018) Evaluation of antiulcerogenic activity of Bacopa Monnieri (Linn.) on ethanol-induced gastric injury in mice. Int J Innov Res Med Sci 3: 196 -211.

83. Tarun V, Yash P (2015) A review on medicinal properties of Carica papaya Linn. Asian Pacific J Trop Dis 5: 1-6.

84. Panzarini E, Dwikat M, Mariano S, Vergallo C, Dini L, (2014) Administration dependent antioxidant effect of Carica papaya seeds water extract. Evid Based Complement Alternat Med pp: 1-14.

85. Eno AE, Owo OI, Itam EH, Konya RS (2000) Blood pressure depression by the fruit juice of Carica papaya (L.) in renal and DOCA-induced hypertension in the rat. Phytother Res 14(4): 235-239.

86. Tona L, Kambu K, Ngimbi N, Cimanga K, Vlietinck AJ (1998) Antiamoebic and phytochemical screening of some Congolese medicinal plants. J Ethnopharmacol 61(1): 57-65.

87. Anibijuwn II, Udeze AO (2009) Antimicrobial activity of Carica papaya (pawpaw leaf) on some pathogenic organisms of clinical origin from South-Western Nigeria. Ethno Leaflets 13: 850-864.

88. Giordani R, Siepaio M, Moulin-Traffort J, Regli P (1991) Antifungal action of Carica papaya latex, isolation of fungal cell wall hydrolyzing enzymes. Mycoses 34(11-12): 469-477.

89. Adebiyi A, Adaikan PG, Prasad RN (2004) Histaminergic effect of crude papaya latex on isolated guinea pig ileal strips. Phytomed 11(1): 65-70.

90. Sripanidkulchai B, Wongpanich V, Laupattarakasem P, Suwansaksri J, Jirakulsomchok D (2001) Diuretic effects of selected Thia indigenous medicinal plants in rats. J Ethnopharmacol 75(2-3): 185-190.

91. Rimbach G, Park YC, Guo Q, Moini H, Qureshi N, et al. (2000) Nitric oxide synthesis and TNF-alpha secretion in RAW264.7 macrophages: mode of action of a fermented papaya prepration. Life Sci 67(6): 679694.

92. Otsuki N, Dang NH, Kumagai E, Kondo A, Iwata S, et al. (2010) Aqueous extract of Carica papaya leaves exhibits anti-tumor and immunomodulatory effects. J Ethnopharmacol 127(3): 760-767.

93. Krishnakumari MK, Majumder SK, (1960) Studies on anthelmintic activities of seeds of Carica papaya Linn. Ann Biochem Exp Med 20: 551-556.

94. Bhat GP, Surolia N (2001) In vitro antimalarial activity of extracts of the three plants used in the tradtitional medicine of India. Am J Trop Hyg 65(4): 304-308.

95. Fekeye TO, Oladipupo T, Showande 0, Ogunremi Y (2007) Effects of co-adminstration of extract of Carica 


\section{Open Access Journal of Pharmaceutical Research}

papaya on activity of two oral hypoglycemic agents. Trop J Pharm Res 6(1): 671-678.

96. Tolunigba AO, Adekunle WO (2012) Gastroproctective activity of aqueous Carica papaya seed extract on ethanol induced gastric ulcer in male rats. Afr J Biotechnol 11(34): 8612-8615.

97. Imaga NOA, Gbenle GO, Okochi VI, Akanbi SO, Edeoghon SO, et al. (2009) Antisickling property of Carica papaya leaf extract. Afr J Biochem Res 3(4): 102-106.

98. Ramandeep K, Kalyan S (2017) Antiulcer activity of hydroalcoholic extract of unripe fruit of Carica papaya in experimental rats. Int J Basic Clin Pharmacol 6(2): 432-440.

99. Arora D, Kumar M, Dubey S (2002) Centella asiatica -a review of its medicinal uses and pharmacological effects. J Nat Remedies 2(2): 143-149.

100. Maquart FX, Bellon G, Gillery P, Wegrowski Y, Borel JP (1990) Stimulation of collagen synthesis in fibroblast cultures by triterpenes extracted from C. asciatica. Connect Tissue Res 24(2): 107-120.

101. Zaunol MK, Abd-Hamid A, Yusof S, Muse R (2003) Antioxidative activity and total phenolic compounds of leaf, root and petiole of four accessions of $\mathrm{C}$. asiatica L. Urban. Food Chem 81(4): 575-581.

102. Cheng CL, Guo JS, Luk J, Koo MW (2004) The healing effects of centella extract and asiaticoside on acetic acid induced gastric ulcer in rats. Life Sci 74(18): 2237-2249.

103. Park BC, Bosire KO, Lee ES, Lee YS, Kim JA (2005) Asiatic acid induces apoptosis in SK-MEL-2 human melanoma cells. Cancer Lett 218(1): 81-90.

104. Zaidan MR, Noor RA, Badrul AR, Adlin A, Norazah A, et al. (2005) In vitro screening of five local medicinal plants for antibacterial activity using diffusion method. Trop Biomed 22(2): 165-170.

105. Guo JS, Cheng CL, Koo MW (2004) Inhibitory effects of C. asiatica water extract and asiaticoside on inducible nitric oxide synthase during gastric ulcer healing in rats. Planta Med 70(12): 1150-1154.

106. Abdulla MA, AL-Bayaty FH, Younis LT, Abu Hassan MI (2010) Anti-ulcer activity of Centella asiatica leaf extract against ethanol-induced gastric mucosal injury in rats. J Med Plants Res 4(13): 1253-1259.
107. Kamran A, Sadia S (2017) A comprehensive review on Curcuma longa Linn.: Phytochemical, pharmacological, and molecular study. Int J Green Pharm 11(4): S671-S685.

108. Srivastava R, Srimal RC (1985) Modification of certain inflammation-induced biochemical changes by curcumin. Indian J Med Res 81: 215-223.

109. Sharma OP (1976) Antioxidant activity of curcumin and related compounds. Biochem Pharmacol 25(15): 1811-1812.

110. Somasundaram S, Edmund NA, Moore DT, Small GW, Shi YY, et al. (2002) Dietary curcumin inhibits chemotherapy-induced apoptosis in models of human breast cancer. Cancer Res 62(13): 3868-3875.

111. Srivastava R, Dikshit M, Srimal RC, Dhawan BN (1985) Anti-thrombotic effect of curcumin. Thromb Res 40(3): 413-417.

112. Arun N, Nalini N (2002) Efficacy of turmeric on blood sugar and polyol pathway in diabetic albino rats. Plant Foods Hum Nutr 57(1): 41-52.

113. Ungphaiboon S, Supavita $T$, Singchangchai $P$, Sungkarak S, Rattanasuwan P, et al. (2005) Study on antioxidant and antimicrobial activities of turmeric clear liquid soap for wound treatment of HIV patients. Songklan J Scitech 27: 269-578.

114. Upendra RS, Khandelwal P, Reddy AH (2011) Turmeric powder (Curcuma longa Linn.) as an antifungal agent in plant tissue culture studies. Int J Eng Sci 3: 7899-7904.

115. Barthelemy S, Vergnes L, Moynier M, Guyot D, Labidalle $S$, et al. (2008) Curcumin and curcumin derivatives inhibit Tat-mediated transactivation of Type 1 human immunodeficiency virus long terminal repeat. Res Virol 149(1): 43-52.

116. Karolin KAA (2011) Comparative evaluation of the anti-ulcer activity of curcumin and omeprazole during the acute phase of gastric ulcer. Food Nutr Sci 2: 628-640.

117. Mehjabeen, Mansoor A, Noorjahan, Farah-Saeed, Asif BR (2015) The role of Elettaria cardamomum (L.) Maton in inflammatory, gastrointestinal and stress disorders. Int J Pharm Phytopharmacol Res 4: 302305. 


\section{Open Access Journal of Pharmaceutical Research}

118. Jamal A, Kalim J, Aslama M, Jafri MA (2006) Gastroprotective effect of cardamom, Elettaria cardamomum Maton. fruits in rats. J Ethnopharmacol 103(2): 149-153.

119. Jadhav V M, Thorat RM, Kadam VJ, Sathe NS (2009) Traditional medicinal uses of Hibiscus rosa-sinensis. J Pharm Res 2(8): 1220-1222.

120. Reddy CM, Murthy DR, Patil SB (1997) Antispermatogenic and androgenic activities of various extracts of Hibiscus rosa sinensis in albino mice. Indian J Exp Biol 35(11): 1170-1174.

121. Serrame E, Lim SCY (1995) Antitumour promoting activity of decoctions and expressed juices from Philippine medicinal plants. Philipine J Sci. 124: 275281.

122. Kasture VS, Chopde CT, Deshmukh VK (2000) Anticonvulsive activity of Albizzia lebbeck, Hibiscus rosa sinensis and Butea monosperma in experimental animals. J Ethnopharmacol 71(1-2): 65-75.

123. Alam MM, Siddiqui MB, Hussai W (1990) Treatment of diabetes through herbal drugs in rural India. Fitoterapia 61: 240-242.

124. Srivastava S, Jaiswal J, Gautam H, Sharma S, Rao CHV (2013) Anti-ulcer activity of methanolic extract of Hibiscus rosa Sinensis leaves. Int J Pharm Sci 5(3): 829-830.

125. Ali M, Ansari SH (1997) Hair care and herbal drugs. Ind J Nat Prods 13: 3-5.

126. Meran KE, Kamani HT, Sameera RS (2017) A Review on Ethnopharmacological Applications, Pharmacological Activities, and Bioactive Compounds of Mangifera indica (Mango). Evid-Based Complementary Altern Med pp: 1-24.

127. Prabhu A, Krishnamoorthy MKM, Prasad DJ, Naik P (2011) Anticancer activity of friedelin isolated from ethanolic leaf extract of Cassia tora on HeLa and HSC1 cell lines. Ind J Appl Res 3(10): 1-4.

128. Marquez L, Perez-Nievas BG, Garate I, García-Bueno B, Madrigal JL, et al. (2010) Anti-inflammatory effects of Mangifera indica L. extract in a model of colitis. World J Gastroenterol 16(39): 4922-4931.

129. Ganogpichayagrai, Palanuvej C, Ruangrungsi N (2017) Antidiabetic and anticancer activities of
Mangifera indica cv. Okrong leaves. J Adv Pharm Technol Res 8(1): 19-24.

130. Mutua JK, Imathiu S, Owino W (2017) Evaluation of the proximate composition, antioxidant potential, and antimicrobial activity of mango seed kernel extracts. Food Sci Nutr 5(2): 349-357.

131. Alok P, Keerthana V, Kumar JC, Ratan K, Chand A D (2013) Antibacterial property of two different varieties of Indian mango (Mangifera indica) kernel extracts at various concentrations against some human pathogenic bacterial strains. Res J Bio Sci 2(4): 28-32.

132. Dorta E, Gonzalez M, Lobo MG, Laich F (2016) Antifungal activity of mango peel and seed extracts against clinically pathogenic and food spoilage yeasts. Nat Pro Res 30(22): 2598-2604.

133. Garcia D, Escalante M, Delgado R, Ubeira FM, Leiro J (2003) Anthelminthic and antiallergic activities of Mangifera indica $L$. stem bark components vimang and mangiferin. Phytother Res 17(10): 1203-1208.

134. Severi JA, Lima ZP, Kushima H, Brito AR, Santos LC, et al. (2009) Polyphenols with antiulcerogenic action from aqueous decoction of mango leaves (Mangifera indica L.). Molecules14(3): 1098-1110.

135. Pourahmad J, Eskandari MR, Shakibaei R, Kamalinejad M (2010) A search for hepatoprotective activity of fruit extract of Mangifera indica L. against oxidative stress cytotoxicity. Plant Food Hum Nutr 65(1): 83-89.

136. Makare N, Bodhankar S, Rangari V (2001) Immunomodulatory activity of alcoholic extract of Mangifera indica L. in mice. J Ethnopharmacol 78(23): 133-137.

137. El-Sherbini GT, Osman SM (2013) Anthelmintic activity of unripe Mangifera indica L. (Mango) against Strongyloides stercoralis. Int J Curr Microbiol Applied Sci 2(5): 401-409.

138. Zeng M, Lu Z (1990) Antiviral effect of mangiferin and isomangiferin on herpes simplex virus. Chinese Med J 103(2): 160-165.

139. Vasant RA, Narasimhacharya AVRL (2011) Antihyperglycemic and antihyperlipemic effects of Mangifera indica $L$. in fluoride induced toxicity. Pharmacologyonline 3: 265-274. 


\section{Open Access Journal of Pharmaceutical Research}

140. Prabhu K, Rajan S (2015) Assessment of antiulcer activity of ethanolic extract of Mangifera indica seed kernel using acid ethanol induced ulcer model. Int J Curr Microbiol App Sci 4(4): 854-860.

141. Vinothapooshan G, Sundar K (2010) Anti-ulcer activity of Mimosa pudica leaves against gastric ulcer in rats. Res J Pharm Biol Chem Sci 1(4): 606-614.

142. Elango V, Carolin O, Raghu PS (2012) Antiulcer activity of the Leaf ethanolic extract of Mimosa pudica in Rats. Hygeia J D Med 4(1): 34-40.

143. Daba M (2016) Miracle Tree: A Review on Multipurposes of Moringa oleifera and Its Implication for Climate Change Mitigation. J Earth Sci Clim Change $7(8): 1-5$.

144. Nair S, Varalakshmi KN (2011) Anticancer, cytotoxic potential of Moringa oleifera extracts on HeLa cell line. J Nat Pharm 2: 138-142.

145. Hukkeri VI, Nagathan CV, Karandi RV, Patil BS (2006) Antipyretic and wound healing activities of Moringa oleifera Lam in rats. Indian J Pharm Sci 68: 124-126.

146. Rao CV, Ojha SK (2003) Analgesic effect of Moringa oleifera Lam leaves extract on rats, Second World Congress on Biotechnological Developments of Herbal Medicine, Lucknow: NBRI 42.

147. Fahey JW (2005) Moringa oleifera: a review of the medical evidence for its nutritional, therapeutic, and prophylactic properties. Trees for Life J 80: 1-5.

148. Rao AV, Devi PU, Kamath R (2001) In vivo radioprotective effect of Moringa oleifera leaves. Ind J Exp Biol 39(9): 858-863.

149. Selvakumar D, Natarajan P (2008) Hepatoprotective activity of Moringa oleifera Lam Leaves in carbon tetrachloride induced hepatotoxicity in Albino rats. Phcog Mag 4: 97-98.

150. Manoj KC, Surendra H, Sanjay KG (2013) Assessment of the antiulcer potential of Moringa oleifera rootbark extract in rats. J Acupunct Meridian Stud 6: 214220.

151. Pattanayak P, Pritishova B, Debajyoti D, Sangram K (2010) Panda Ocimum sanctum Linn. A reservoir plant for therapeutic applications: An overview. Pharmacogn Rev, 4(7): 96-105.
152. Gupta SK, Prakash J, Srivastav S (2002) Validation of traditional claim of Tulsi, Ocimum sanctum Linn. as a medicinal plant. Indian J Exp Biol 40(7): 765-773.

153. Sharm M, Kishore K, Gupta SK, Joshi S, Arya DS (2001) Cardioprotective potential of Ocimum sanctum Linn in isoproterenol induced myocardial infraction in rats. Mol Cell Biochem 225(1): 75-83.

154. Shetty S, Udupa S, Udupa L, Somayaji N (2006) Wound healing activity of Ocimum sanctum Linn with supportive role of antioxidant enzymes. Indian J Physiol Pharmacol 50(2): 163-168.

155. Bhartiya US, Raut YS, Joseph LJ (2006) Protective effect of Ocimum sanctum $\mathrm{L}$ after high-dose 131iodine exposure in mice: An in vivo study. Indian J Exp Biol 44(8): 647-652.

156. Dharmani P, Kuchibhotla VK, Maurya R, Srivastava S, Sharma S, et al. (2004) Evaluation of anti-ulcerogenic and ulcer healing properties of Ocimum sanctum Linn. J Ethnophamacol 93(2-3): 197-206.

157. Singh S, Malhotra M, Majumdar DK (2005) Antibacterial activity of Ocimum sanctum L. fixed oil. Indian J Exp Biol 43(9): 835-837.

158. Mediratta PK, Sharma KK, Singh S (2002) Evaluation of immunomodulatory potential of Ocimum sanctum seed oil and its possible mechanism of action. J Ethnopharmacol 80(1): 15-20.

159. Godhwani S, Godhwani JL, Vyas DS (1988) Ocimum sanctum: A prelimnary study evaluating its immunoregulatory profile in albino rats. J Ethnopharmacol 24(2-3): 193-198.

160. Shokeen P, Ray K, Bala M, Tondon V (2005) Prelimnary studies on activity of Ocimum sanctum, Drynaria quercifolia, and Annona squamosa against Neisseria gonorrohoeae. Sex Transm Dis 32(2): 106111.

161. Ahmed M, Ahamed RN, Aladakatti RH, Ghosesawar MG (2002) Reversible anti-fertility effect of benzene extract of Ocimum sanctum leaves on sperm parameters and fructose content in rats. J Basic Clin Physiol Pharmacol 13(1): 51-59.

162. Asha MK, Prashanth D, Murali B, Padmaja R, Amit A (2001) Anthelmintic activity of essential oil of Ocimum sanctum and eugenol. Fitoterapia 72(6): 669-670. 


\section{Open Access Journal of Pharmaceutical Research}

163. Karthikeyan K, Ravichandran P, Govindasamy S (1999) Chemopreventive effect of Ocimum sanctum on DMBA-induced hamster buccal pouch carcinogenesis. Oral Oncol 35(1): 112-119.

164. Panda S, Kar A (1998) Ocimum sanctum leaf extract in the regulation of thyroid function in the male mouse. Pharmacol Res 38(2): 107-110.

165. Bharat BM, Mangala CD, Subas CD, Nagojia KEV (2012) Anti-ulcer activity of aqueous and ethanolic leaf extract of Tulasi (Ocimum sanctum) in Albino rats. J Pharm Res 5(8): 4060-4062.

166. Damanhouri ZA, Ahmad A (2014) A Review on therapeutic potential of Piper nigrum L. (Black Pepper): The king of spices, medicinal \& aromatic plants. Med Aromat Plants 3: 1-6.

167. Taqvi SI, Shah AJ, Gilani AH (2008) Blood pressure lowering and vaso modulator effects of piperine. J Cardiovasc Pharmacol 52(5): 452-458.

168. Ahmad N, Fazal H, Abbasi BH, Farooq S, Ali M (2012) Biological role of Piper nigrum L. (Black pepper): A review. Asian Pacific J Trop Biomed 2(2): S1945S1953.

169. Sunila ES, Kuttan G (2004) Immunomodulatory and antitumor activity of Piper longum Linn. and piperine. J Ethnopharmacol 90(2-3): 339-346.

170. Parganiha R, Verma S, Chandrakar S, Pal S, Sawarkar HA, et al. (2011) In vitro anti-asthmatic activity of fruit extract of Piper nigrum (Piperaceae). Inter J Herbal Drug Res 1: 15-18.

171. Bukhari IA, Pivac N, Alhumayyd MS, Mahesar AL, Gilani AH (2013) The analgesic and anticonvulsant effects of piperine in mice. J Physiol Pharmacol 64(6): 789-794.

172. Bang JS, Oh da H, Choi HM, Sur BJ, Lim SJ, et al. (2009) Anti-inflammatory and antiarthritic effects of piperine in human interleukin 1beta-stimulated fibroblast-like synoviocytes and in rat arthritis models. Arthritis Res Ther 11(2): R49.

173. Shamkuwar PB, Shahi SR, Jadhav ST (2012) Evaluation of antidiarrhoeal effect of Black pepper (Piper nigrum L). Asian J Plant Sci Res 2(1): 48-53.

174. Li S, Wang C, Wang M, Li W, Matsumoto K (2007) Antidepressant like effects of piperine in chronic mild stress treated mice and its possible mechanisms. Life Sci 80(15): 1373-1381.

175. Matsuda H, Ninomiya K, Morikawa T, Yasuda D, Yamaguchi I, et al. (2008) Protective effects of amide constituents from the fruit of Piper chaba on Dgalactosamine/TNF-alpha-induced cell death in mouse hepatocytes. Bio-org Med Chem Lett 18(6): 2038-2042.

176. Kumar KP, Gnanajobitha G, Vanaja M, Kumar SR, Malarkodi C, et al. (2014) Piper nigrum leaf and stem assisted green synthesis of silver nanoparticles and evaluation of its antibacterial activity against agricultural plant pathogens. Sci World J pp: 1-9.

177. Wattanathorn J, Chonpathompikunlert $P$, Muchimapura S, Priprem A, Tankamnerdthai 0 (2008) Piperine, the potential functional food for mood and cognitive disorders. Food Chem Toxicol 46(9): 3106-3110.

178. Johnson JJ, Nihal M, Siddiqui IA, Scarlett CO, Bailey $\mathrm{HH}$, et al. (2011) Enhancing the bioavailability of resveratrol by combining it with piperine. Mol Nutr Food Res 55(8): 1169-1176.

179. Muna HA (2014) Study the Effect of Aqueous Extract of Piper nigrum on Some physiological parameters and Histopathological in Female Rabbit Induced Gastric Ulceration by Aspirin. J Kerbala Uni 12(1): 1932.

180. Bhattacharya A, Ghosal S, Bhattacharya SK (2000) Antioxidant activity of tannoid principles of Emblica officinalis (amla) in chronic stress induced changes in rat brain. Indian J Exp Biol 38(9): 877-880.

181. Ngamkitidechakul C, Jaijoy K, Hansakul P, Soonthornchareonnon N, Sireeratawong S (2010) Antitumour effects of Phyllanthus emblica L.: Induction of cancer cell apoptosis and inhibition of in vivo tumour promotion and in vitro invasion of human cancer cells. Phytother Res 24(9): 1405-1413.

182. Kaur S, Arora S, Kaur K, Kumar S (2002) The invitroantimutagenic activity of Triphala--an Indian herbal drug. Food Chem Toxicol 40(4): 527-534.

183. Asmawi MZ, Kankaanranta H, Moilanen E, Vapaatalo $\mathrm{H}$ (1993) Anti-inflammatory activities of Emblica officinalis Gaertn leaf extracts. J Pharm Pharmacol 45(6): 581-584. 


\section{Open Access Journal of Pharmaceutical Research}

184. Akhtar MS, Ramzan A, Ali A, Ahmad M (2011) Effect of Amla fruit (Emblica officinalis Gaertn.) on blood glucose and lipid profile of normal subjects and type 2 diabetic patients. Int J Food Sci Nutr 62(6): 609-616.

185. Dhingra D, Joshi P, Gupta A, Chhillar R (2012) Possible involvement of monoaminergic neurotransmission in antidepressant-like activity of Emblica officinalis fruits in mice. CNS Neurosci Ther 18(5): 419-425.

186. Sairam K, Rao Ch V, Babu MD, Kumar KV, Agrawal VK, et al. (2002) Antiulcerogenic effect of methanolic extract of Emblica officinalis: An experimental study. J Ethnopharmacol 82(1): 1-9.

187. Sumitra M, Manikandan P, Gayathri VS, Mahendran P, Suguna L (2009) Emblica officinalis exerts wound healing action through up-regulation of collagen and extracellular signal-regulated kinases (ERK1/2). Wound Repair Regen 17(1): 99-107.

188. Head KA (2001) Natural therapies for ocular disorders, part two: Cataracts and glaucoma. Altern Med Rev 6(2): 141-166.

189. Patel SS, Goyal RK (2011) Prevention of diabetesinduced myocardial dysfunction in rats using the juice of the Emblica officinalis fruit. Exp Clin Cardiol 16(3): 87-91.

190. Kulkarni AP, Kellaway LA, Kotwal GJ (2005) Herbal complement inhibitors in the treatment of neuroinflammation: Future strategy for neuroprotection. Ann N Y Acad Sci. 1056: 413-429.

191. Joshy S, Shirish, Snehalata V, Gajbhiye, Urmila T (2016) Evaluation of gastric motility of Phyllanthus emblica and Asparagus racemosus in cold stress induced gastric damage, Int J Basic Clin Pharmacol 5(4): 1516-1519.

192. Raju D, Ilango K, Chitra V, Ashish K (2009) Evaluation of anti-ulcer activity of methanolic extract of Terminalia chebula fruits in experimental rats. J Pharm Sci Res 1(3): 101-107.

193. Chattopadhyay RR, Bhattacharyya SK (2007) Plant review Terminalia chebula: An Update. Pharmacog Rev 1: 151-156.

194. Jyotsna D, Neelam A, Viveka N (2017) A Review on Zingiber officinale. J Pharma Phytochem 6(3): 174184.
195. Chen IN, Chang CC, Ng CC, Wang CY, Shyu YT, et al. (2008) Antioxidant and antimicrobial activity of Zingiberaceous plants in Taiwan. Plants Foods Hum Nutr 63(1): 15-20.

196. Ling H, Yang H, Tan SH, Chui WK, Chew EH (2010) 6Shogaol, an active constituent of ginger, inhibits breast cancer cell invasion by reducing matrix metalloproteinase- 9 expression via blockade of nuclear factor- $\kappa \mathrm{B}$ activation. Br J Pharmacol 161(8): 1763-1777.

197. Akhani SP, Vishwakarma SL, Goyal RK (2004) Antidiabetic activity of Zingiber officinale in streptozotocin-induced type I diabetic rats. J of Phar and Pharmaco 56(1): 101-105.

198. Thomson M, Al-Qattan KK, Al-Sawan SM, Alnaqeeb MA, Khan I, et al. (2002) The use of ginger (Zingiber officinale Rosc.) as a potential anti-inflammatory and antithrombotic agent. Prostaglandins Leukot Essent Fatty Acids. 67(6): 475-478.

199. Onogi T, Minami M, Kuraishi Y, Satoh M (1992) Capsaicin-like effect of (6)-shogaol on substance Pcontaining primary afferents of rats: a possible mechanism of its analgesic action. Neuropharmacol 31(11): 1165-1169.

200. Mascolo N, Jain R, Jain SC, Capasso F (1989) Ethnopharmacologic investigation of ginger (Zingiber officinale). J Ethnopharmacol 27(1-2): 129-140.

201. Wilasrusmee C, Siddiqui J, Bruch D, Wilasrusmee S, Kittur S, et al. (2000) In vitro immunomodulatory effects of herbal products. Am Surg 68(10): 860-864.

202. Liao YR, Leu YL, Chan YY, Kuo PC, Wu TS (2012) Antiplatelet aggregation and vasorelaxing effects of the constituents of the rhizomes of Zingiber officinale. Molecules 17(8): 8928-8937.

203. Kim EC, Min JK, Kim TY, Lee SJ, Yang HO, et al. (2005) [6]-Gingerol, a pungent ingredient of ginger, inhibits angiogenesis in vitro and in vivo. Biochem Biophys Res Commun 335(2): 300-308.

204. Khaki AA, Khaki A (2010) Antioxidant effect of ginger to prevents lead-induced liver tissue apoptosis in rat. J Med Plants Res 4(14): 1492-1495.

205. Lumb AB (1993) Mechanism of antiemetic effect of ginger. Anaesthesia 48(12): 1118-1119. 


\section{Open Access Journal of Pharmaceutical Research}

206. Ha SK, Moon E, Ju MS, Kim DH, Ryu JH, et al. (2012) 6-Shogaol, a ginger product, modulates neuro inflammation: a new approach to neuroprotection. Neuropharmacol 63(2): 211-223.

207. Iqbal Z, Nadeem QK, Khan MN, Akhtar MS, Waraich FN (2001) In vitro anthelmintic activity of Allium sativum, Zingiber officinale, Curcurbita mexicana and Ficus religiose. Int J Agri Biol 3(4): 454-457.

208. Yamahara J, Mochizuki M, Rong HQ, Matsuda H, Fujimura $H$ (1988) The anti-ulcer effect in rats of ginger constituents. J Ethnopharmacol 23(2-3): 299304.

209. Ghayur MN, Gilani AH (2005) Ginger lowers blood pressure through blockade of voltage dependent calcium channels. J Cardiovasc Pharmacol 45(1): 7480.

210. Sameer UZ, Mrutyunjay MM, Ramabhimaiah S (2014) Evaluation of the anti-ulcerogenic effect of Zingiber officinale (Ginger) root in rats. Int J Curr Microbiol App Sci 3(1): 347-354.

211. Prabjone R, Thong-Ngam, Wisedopas N, Chatsuwan T, Patumraj S (2006) Anti-inflammatory effects of Aloe vera on leukocyte-endothelium interaction in the gastric microcirculation of Helicobacter pyloriinfected rats. Clin Hemorheol Microcirc 35(3): 359366.

212. Hoffman BB (2007) Fa'rmacos antagonistas dos adreno receptores. In: Katzung, B.G. (Ed.), Farmacologia ba' sica e clı́nica. $10^{\text {th }}$ (Edn.). McGrawHill, Sa o Paulo pp: 127-141.

213. Sairam K, Rao Ch V, Dora Babu M, Vijay K, Agrawal VK, et al. (2002) Antiulcerogenic effect of methanolic extract of Emblica officinalis: an experimental study. J Ethnopharmacol 82(1): 1-9

214. Nethravathi K, Chandrashekhar MS, Siddique TA, Lakshminarayana G (2015) Evaluation of antiulcer activity of Mangifera indica kernel, vitamins and zinc sulphate on pylorus ligation and ethanol induced ulcer models in rats. Int J Phytopharmacol 6: 86-97.

215. Severi JA, Lima ZP, Kushima H, Brito AR, Santos LC, et al. (2009) Polyphenols with antiulcerogenic action from aqueous decoction of mango leaves (Mangifera indica L.). Molecules 14(3): 1098-1110.

216. Khushtar M, Kumar V, Javed K, Uma Bhandari (2009) Protective Effect of ginger oil on aspirin and pylorus ligation-induced gastric ulcer model in rats. Indian J Pharm Sci 71(5): 554-558.

217. Siddaraju MN, Harish NM, Shylaja MD (2010) Gastroprotective effect of ginger rhizome (Zingiber officinale) extract: Role of gallic acid and cinnamic acid in $\mathrm{H}+\mathrm{K}+-\mathrm{ATPase} / \mathrm{H}$. pylori inhibition and antioxidative mechanism. EBCAM pp: 1-13.

218. Rang HP, Ritter JM, Flower RJ, Henderson G (2016) The gastrointestinal tract. Rang and Dales pharmacology 8: 669 .

219. Heloina SF, Jacqueline AL, Jose MBF, Petronio F, Maria COC, et al. (2008) Gastric and duodenal antiulcer activity of alkaloids: A review. Molecules 13(2): 3198-3223.

220. Neyres ZTJ, Heloina SF, Isis FG, Thiago JAL, Gedson RML, et al. (2012) Tannins, peptic ulcers and related mechanisms. Int J Mol Sci 13(3): 3203-3228.

221. Francisco de AO, Luciana NA, Elida BV, Pergentino de S (2014) Anti-ulcer activity of essential oil constituents. Molecules 19(5): 5717-5747.

222. Kelly SLM, Guilherme END, Meri EFP, Anderson LF, Alba RMS, et al. (2009) Flavonoids with gastroprotective activity. Molecules 14(3): 979-1012. 